\title{
Review
}

\section{Long-Term Performance of Zero-Valent Iron Permeable Reactive Barriers: A Critical Review}

\author{
Andrew D. Henderson* and Avery H. Demond \\ Department of Civil and Environmental Engineering \\ The University of Michigan \\ Ann Arbor, MI 48109-2125
}

\begin{abstract}
Permeable reactive barriers (PRBs) have shown great promise as an alternative to pump and treat for the remediation of groundwater containing a wide array of contaminants including organics, metals, and radionuclides. Analyses to date have focused on individual case studies, rather than considering broad performance issues. In response to this need, this study analyzed data from field installations of in situ zerovalent iron (ZVI) PRBs to determine what parameters contribute to PRB failure. Although emphasis has been placed on losses of reactivity and permeability, imperfect hydraulic characterization was the most common cause of the few PRB failures reported in the literature. Graphical and statistical analyses suggested that internal $\mathrm{E}_{\mathrm{H}}$, influent $\mathrm{pH}$, and influent concentrations of alkalinity, $\mathrm{NO}_{3}{ }^{-}$and $\mathrm{Cl}^{-}$are likely to be the strongest predictors of PRBs that could be at risk for diminished performance. Parameters often cited in the literature such as saturation indices, dissolved oxygen, and total dissolved solids did not seem to have much predictive capability. Because of the relationship between the predictive parameters and corrosion inhibition, it appears that reactivity of the ZVI, rather than the reduction in permeability, is more likely the factor that limits PRB longevity in the field. Due to the sparseness of field monitoring of parameters such as $E_{H}$, the data available for these analyses were limited. Consequently, these results need to be corroborated as additional measurements become available.
\end{abstract}

Key words: permeable reactive barrier; groundwater remediation; performance; reactivity; precipitates; failure

\section{INTRODUCTION}

$\mathbf{T}$ IRADITIONAL GROUNDWATER REMEDIATION METHODS such as pump and treat are of questionable utility: a 1994 study found that 69 of 77 treatment sites using pump and treat had not met cleanup goals (National Research
Council, 1994). Permeable reactive barriers (PRBs) are a promising remediation option involving the emplacement of a hydraulically permeable reactive medium downgradient of a plume of contaminated groundwater. As the water flows through it under the natural hydraulic gradient, the reactive medium degrades or traps the con-

\footnotetext{
*Corresponding author: Department of Civil and Environmental Engineering, The University of Michigan, 1351 Beal Avenue, Ann Arbor, MI 48109-2125. Phone: 734-615-5903; Fax: 734-763-2275; E-mail: henderad@umich.edu
} 
taminants. Because PRBs offer the possibility of (1) in situ plume capture and treatment, obviating the need to manage large volumes of water containing low concentrations of contaminants and the waste generated from the treatment of such water (Blowes et al., 1999); (2) the simultaneous treatment of multiple types of contaminants such as metals, organics, and radionuclides; and (3) low operation and maintenance costs (Powell et al., 1998), they are an alternative remediation technology that has received considerable attention as of late (EPA, 2002; Tratnyek, 2002).

PRBs are a relatively new technology; the oldest fullscale PRB has been in operation for just over a decade. Original work using reduced metals for the treatment of chlorinated organics built on studies of the corrosive effects of chemicals on metals (e.g., Rhodes and Carty, 1925). More recent work began in the 1970s (Sweeny and Fischer, 1972, 1973; Sweeny, 1981a, 1981b) and continued through the 1980s (Senzaki and Kumagai, 1988, 1989; Senzaki, 1991), culminating in a pilot-scale PRB installed in 1991 at the Borden, Ontario site (Reynolds et al., 1990; Gillham and O'Hannesin, 1992; O'Hannesin, 1993; Gavaskar et al., 1997; Morrison et al., 2002d), and a full-scale PRB installed in 1995 at the Intersil Site in Sunnyvale, CA (Warner et al., 2005). Although the Borden PRB did not achieve its removal targets, it was felt that increasing the reactive media to sand ratio (installed as 20:80) would have resulted in complete removal of contaminants (O'Hannesin and Gillham, 1998). The Intersil PRB, on the other hand, used pure $\mathrm{ZVI}$ in the reactive zone and was still meeting its cleanup goals as of 2004 (Sorel et al., 2003; Warner et al., 2005).

With the initial success of PRBs, their use has become more widespread. PRBs have been installed to treat organics, heavy metals, radionuclides, and nutrients (RTDF, 2001), with nearly 50\% treating organic contam- inants and nearly $20 \%$ treating metals as of 2002 (EPA, 2002). The reactive medium may consist of ZVI, cast iron, steel wool, amorphous ferric oxide, phosphate, zeolite, activated carbon, or limestone, among others (see Scherer et al., 2000); however, of the over 200 PRBs worldwide as of 2004, 120 are iron based (90 in the United States) (ITRC, 2005).

Despite the numerous installations, PRBs are still considered an experimental technology (Warner and Sorel, 2003), perhaps because their long-term performance is not well understood. As Wilkin and Puls (2003) point out, "[f]ew case studies are available that evaluate the long-term performance of these in-situ systems, especially with respect to the long-term efficiency of contaminant removal, the buildup of mineral precipitates, and the buildup of microbial biomass." With the lack of comprehensive retrospective studies, there is disagreement about what factors control PRB longevity, defined as the length of time that a PRB continues to treat groundwater to design levels. Some have argued that PRB longevity is controlled by loss of reactivity (e.g., Roberts et al., 2002; Vikesland et al., 2003), whereas others assert that reduction in permeability is more important (e.g., Phillips et al., 2000; Liang et al., 2003) (Table 1). Depending on assumptions about controlling factors, estimates of PRB longevity can vary by an order of magnitude (e.g., 10 to 117 years for Monticello, UT), as shown in Table 2.

Another impediment to accurate longevity estimation is the difficulty of comparing laboratory column studies with field installations. Laboratory columns are generally aerobic, confined systems, whereas field PRBs are anoxic and unconfined. Studies utilizing high contaminant concentrations may not adequately represent long-term, low contaminant fluxes (Melitas et al., 2002). Short-term column studies with high flow rates-intended to speed the aging of the reactive media and mimic long time scales-

Table 1. Factors postulated to control PRB longevity.

Factor Reference

Loss of media reactivity caused by high TDS and high flow rates.

ESTCP, 2003

Loss of porosity - concentrated at influent interface.

Competition for reactive sites, loss of reactive sites (due to corrosion or fouling), or

Liang et al., 2003

precipitation and loss of permeability resulting from high carbonate, high nitrate, high DOC, and high TDS.

Loss of reactivity due to iron corrosion resulting from high influent concentrations of inorganic species such as bicarbonate, sulfate, or nitrate.

Loss of media reactivity and decreases in hydraulic residence time.

Clogging due to precipitation resulting from high DO, carbonates, or sulfates.

Clogging due to precipitation resulting from high DO.

Wilkin and Puls, 2003

Gu et al., 1999, 2002

Roberts et al., 2002

Korte, 2001

Gavaskar, 1999;

Mackenzie et al., 1999

DO, dissolved oxygen; DOC , dissolved organic carbon; TDS, total dissolved solids. 
Table 2. Select longevity estimates for in situ PRBs.

\begin{tabular}{|c|c|c|c|c|}
\hline Site & Estimate & Basis of estimate & Contaminant & Ref. \\
\hline \multirow[t]{2}{*}{ Elizabeth City, NC } & 20 years & $\begin{array}{l}\text { Oxidation of ZVI by all species in } \\
\text { groundwater, based on laboratory } \\
\text { studies. }\end{array}$ & $\mathrm{Cr} ; \mathrm{TCE}$ & Blowes et al., 2000 \\
\hline & 750 years & $\begin{array}{l}\text { Oxidation of all ZVI by } \mathrm{Cr}(\mathrm{VI}) \text { only } \\
\text { (theoretical). }\end{array}$ & & \\
\hline \multirow[t]{3}{*}{ Monticello, UT } & 10 years & $\begin{array}{l}\text { Precipitation of calcite and resultant pore } \\
\text { blockage, based on } \mathrm{Ca}^{2+} \text { mass balance. }\end{array}$ & $\begin{array}{l}\mathrm{U} ; \mathrm{Mn} ; \mathrm{Mo} ; \mathrm{NO}_{3}^{-} \\
\quad \text { As; } \mathrm{Se} ; \mathrm{V}\end{array}$ & Morrison et al., 2002a \\
\hline & 36 years & $\begin{array}{l}\text { Passivation of iron surfaces (estimated } \\
\text { by } 35 \% \text { loss of "reactivity efficiency" } \\
\text { measured in PRB during first } 7 \text { months } \\
\text { of operation). }\end{array}$ & & \\
\hline & 117 years & $\begin{array}{l}\text { Dissolution of ZVI, based on effluent } \\
\mathrm{Fe}^{2+} \text { measured in column tests. }\end{array}$ & & \\
\hline $\begin{array}{l}\text { Y-12 Plant } \\
\text { (Pathway 2), } \\
\text { Oak Ridge, TN }\end{array}$ & $>15$ years & Visual inspection of corrosion of ZVI. & $\mathrm{U} ; \mathrm{NO}_{3}^{-}$ & Phillips et al., 2000 \\
\hline
\end{tabular}

may not be representative of true media aging (Gu et al., 1999; Farrell et al., 2000; Sarr, 2001; Roberts et al., 2002; Kamolpornwijit et al., 2003). Many laboratory studies have used feed water that is not representative of natural systems (Liang et al., 2000; Roberts et al., 2002) and the use of different buffering agents is problematic, as some agents have been shown to alter iron corrosion rates (Uhlig and Revie, 1985; O'Hannesin and Gillham, 1998). Thus, assessments of PRB longevity based on laboratory studies (e.g., Liang et al., 1997; Mackenzie et al., 1999; Simon et al., 2001; Morrison et al., 2002b; Kamolpornwijit et al., 2003; Johnson et al., 2005) may not be applicable to in situ PRBs.

Because of these uncertainties, there have been frequent calls in the literature for more comprehensive reporting and analysis of field data (e.g., Scherer et al., 2000; Liang et al., 2001; Yabusaki et al., 2001; Morrison et al., 2002c; Powell and Powell, 2002; Roberts et al., 2002; Phillips et al., 2003; Devlin and Allin, 2005). The collections of PRB performance data that do exist, such as the Remediation Technologies Development Forum (RTDF) Web site (RTDF, 2001), do not necessarily collect uniform data, nor do they look broadly at trends. On the other hand, there are efforts to develop predictive models for declines in PRB performance (Liang et al., 2001; Li and Benson, 2005), and to determine the geochemical parameters that adversely affect PRB performance (Wilkin and Puls, 2003); yet these studies have not been substantiated by an analysis of field data. In order to establish PRBs as an accepted technology, it is necessary to review PRB performance to date, with a focus on elucidating the factors that contribute to longevity in the field.

\section{BACKGROUND}

\section{PRB configuration}

PRBs have traditionally been emplaced via excavation and backfilling with reactive media (Gavaskar, 1999), with typical dimensions being 2 to $50 \mathrm{~m}$ long (transverse to flow), $<1$ to $5 \mathrm{~m}$ wide (parallel to flow), and $<1$ to $10 \mathrm{~m}$ deep (RTDF, 2001). The backfilled reactive media may be mixed with nonreactive media, such as sand. Some researchers report that this mixing does not affect removal of contaminants (e.g., Kjeldsen and Locht, 2000), others assert that it does affect removal (e.g., Liang et al., 2000; D'Andrea et al., 2005), whereas still others state that mixing is useful since using larger grained media can decrease the hydraulic impact of precipitates $(\mathrm{Fu}-$ rukawa et al., 2002).

PRBs may also make use of a pretreatment zone (PTZ), which is placed immediately upgradient of the main body of a PRB and contains a mixture of reactive media and gravel or sand. The high porosity of a PTZ allows for precipitate formation without undue permeability reduction, and can reduce potential clogging at the upgradient face of the main body of a PRB (Dwyer, 2000; Sarr, 2001). While a true PTZ should contain reactive media, some upgradient zones consist of pure sand or gravel. With a higher hydraulic conductivity - especially in the vertical direction-than the native aquifer material, these zones are intended for improved hydraulic distribution of the contaminated groundwater over the face of the PRB. However, these zones have sometimes been observed to degrade contaminants (e.g., at the Denver Federal Center, CO, and Intersil, CA, PRBs), possibly due to the inadvertent mixing 
of reactive media into the upgradient nonreactive zone during installation (Blowes et al., 1999; RTDF, 2001).

PRBs may also be constructed ex situ, such as at the Portsmouth Groundwater Treatment Facility (Piketon, OR) (Korte et al., 1997b) or the Uranium Mill Tailings Remedial Action (UMTRA) Site (Durango, CO) (Morrison et al., 2002c). At these sites, groundwater is passively collected in gravel-filled trenches and then directed through containers filled with reactive media located below the hydraulic grade line. With the absence of pumping and the frequent use of ZVI, these ex situ systems are conceptually similar to in situ PRBs, though their performance may differ significantly.

\section{PRB geochemistry}

ZVI, the reactive medium selected predominantly for PRBs, treats contaminated groundwater through a combination of redox processes (some of which may be biologically mediated, such as the reduction of sulfate), precipitation reactions, and sorption. The specific reactions depend on the contaminant(s) and the constituents in the native groundwater, but in the case of both chlorinated organics and heavy metals, the chemical reaction is surface-mediated and requires contact between a reactive surface site and the contaminant (Weber, 1996).

Chlorinated organics are removed via the coupling of the oxidation of ZVI with the reductive dechlorination of the organic, $\mathrm{RCl}$ (Powell et al., 1998):

$$
\mathrm{Fe}^{0}+\mathrm{RCl}+\mathrm{H}^{+}=\mathrm{Fe}^{2+}+\mathrm{RH}+\mathrm{Cl}^{-}
$$

Possible removal mechanisms for metals are surface adsorption via electrostatic attraction, surface complexation (Scherer et al., 2000), or (co)precipitation, which may be coupled to redox reactions for redox-active species (Lien and Wilkin, 2005, and references therein). Equations (2) and (3) show the reduction of chromium to a more insoluble form and the precipitation of a mixed $\mathrm{Fe} / \mathrm{Cr}$ solid (Powell et al., 1998):

$$
\begin{aligned}
& \mathrm{CrO}_{4}^{2-} \\
& +\frac{3}{2} \mathrm{Fe}^{0}(\mathrm{~s})+4 \mathrm{H}_{2} \mathrm{O}=\mathrm{Cr}^{3+}+\frac{3}{2} \mathrm{Fe}^{2+}+8 \mathrm{OH}^{-} \\
& (1-\mathrm{x}) \mathrm{Fe}^{3+}+(\mathrm{x}) \mathrm{Cr}^{3+}+2 \mathrm{H}_{2} \mathrm{O} \\
& =\mathrm{Fe}_{(1-\mathrm{x})} \mathrm{Cr}_{\mathrm{x}} \mathrm{OOH}(\mathrm{s})+3 \mathrm{H}^{+}
\end{aligned}
$$

Field data indicate that chromium removed in PRBs is indeed in the trivalent state, although the solids into which it is incorporated are not limited to iron (oxy)hydroxides, as shown above (Wilkin et al., 2005).

In addition to the contaminants, water itself and the constituents in the native groundwater interact with the reactive media. Indeed, the contaminant of interest is usually not the controlling oxidizer of the reactive media (Gillham and O'Hannesin, 1994), as other species are present in greater stoichiometric abundance. For example, the reduction of sulfate was estimated to consume 50 times more ZVI than the reduction of $\mathrm{Cr}(\mathrm{VI})$ in the USCG PRB (Elizabeth City, NC) (Mayer, 1999).

ZVI may be oxidized by water, increasing $\mathrm{pH}$, and producing hydrogen gas:

$$
\mathrm{Fe}^{0}(\mathrm{~s})+2 \mathrm{H}_{2} \mathrm{O}=\mathrm{Fe}^{2+}+\mathrm{H}_{2}(\mathrm{~g})+2 \mathrm{OH}^{-}
$$

If dissolved oxygen is present, ZVI may be oxidized to ferrous or ferric iron, with a concomitant rise in $\mathrm{pH}$ :

$$
2 \mathrm{Fe}^{0}(\mathrm{~s})+\mathrm{O}_{2}+2 \mathrm{H}_{2} \mathrm{O}=2 \mathrm{Fe}^{2+}+4 \mathrm{OH}^{-}
$$

The anaerobic oxidation of ZVI may also proceed abiotically through the reduction of nitrate to ammonia or nitrogen (Kielemoes et al., 2000), or via the biologically mediated reduction of sulfate to sulfide (Al-Agha et al., 1995).

With the emplacement of ZVI in an aquifer, an excess of electrons is introduced into the system; as the oxidation of ZVI proceeds, these electrons become available. Indeed, a dramatic reduction in the reduction-oxidation potential, or $E_{H}$, is known to accompany the oxidation of iron and has been observed in most PRBs (Powel et al., 1998). Wilkin and Puls (2003) showed that for iron redox couples [e.g., $\mathrm{Fe}^{2+}$ with $\mathrm{Fe}(\mathrm{OH})_{3}(\mathrm{~s})$ ], an increase in $\mathrm{pH}$ is accompanied by a decrease in $E_{H}$. In this reducing, alkaline environment, precipitation of solids from native groundwater constituents is favored, leading to the loss of permeability and the possible passivation of the reactive media.

\section{$P R B$ precipitate mineralogy}

A variety of precipitation products have been identified in field PRBs: iron (hydr)oxides, iron and calcium carbonates, iron sulfides, and green rusts (e.g., Liang et al., 2003; Jambor et al., 2005). These precipitates dominate any solids formed with the contaminant. For example, at the UMTRA site (Durango, CO), uranium made up only $0.2 \%$ (by weight) of the precipitates (Matheson et al., 2002) and solid-phase uranium was below the detection limit at the Y-12 site (Oak Ridge, TN), although it was being removed in the barrier (Phillips et al., 2000). The exact composition of the solids is difficult to pinpoint, since the metastable nature of the iron species compromises the analysis. For ZVI under field conditions, $\mathrm{Fe}(\mathrm{OH})_{2}$ is usually one of the first precipitates formed (Farrell et al., 2000); this precipitate may be oxidized to the electrically conductive species magnetite, or to reactive, yet metastable, green rusts (Melitas et al., 2002; Rit- 
ter et al., 2002; Phillips et al., 2003; Su and Puls, 2004). Continued oxidation may produce poorly crystalline ferric oxyhydroxides such as ferrihydrite, which may age to more crystalline forms, such as goethite $(\alpha-\mathrm{FeOOH})$ and lepidocrocite $(\gamma-\mathrm{FeOOH})$ (Abdelmoula et al., 1996).

Each of these mineral species will have different interactions with contaminants, and may enhance, reduce, or alter the reaction mechanism (e.g., ferrihydrite may sorb rather than degrade some organics) (Furukawa et al., 2002). Of particular concern are the carbonate and iron (hydr)oxide solids that may form. First, these solids have been observed to dominate precipitates in many PRBs (Gillham, 1999). Second, carbonate solids (Köber et al., 2002; Roberts et al., 2002; Klausen et al., 2003; Devlin and Allin, 2005) and iron (hydr)oxides (Ritter et al., 2002) have been shown to passivate iron surfaces.

Even electrically conductive layers, such as magnetite, may passivate the reactive media if they inhibit the movement of $\mathrm{Fe}^{2+}$ to solution (Farrell et al., 2000). Reactivity of surface layers is a function of morphology, distribution, and type of precipitates. For example, the "incoherent and porous" surface of (hydr)oxide solids often allows for continued reaction (Tratnyek, 1996), though (hydr)oxide surfaces tend to inhibit corrosion (Johnson et al., 1998). The distribution of precipitates also controls reactivity, as precipitates may occur on nonreactive sites with little passivating effect (Deng et al., 2003).

\section{Corrosion and media aging}

Corrosion directly or indirectly drives contaminant treatment. Equations (1) and (2) are examples of the direct coupling of contaminants to the corrosion process, while the sorption of metals to (oxy)hydroxides relies on corrosion to produce these solids. Because metals may be immobilized through surface complexation reactions without redox changes, changes in corrosion rates due to, for example, the buildup of passivating layers, will affect removal of metals and organics differently (Devlin and Allin, 2005).

In general, higher concentrations of anions tend to increase corrosion (Liang et al., 2003; Devlin and Allin, 2005) and thus iron reactivity, but this is not always the case. Chloride and sulfate have been found to increase iron corrosion and destabilize passivating films (Johnson et al., 1998; Devlin and Allin, 2005). Nitrate has been shown to inhibit corrosion (Farrell et al., 2000; Schlicker et al., 2000; D'Andrea et al., 2005; Devlin and Allin, 2005), as well as nullify the corrosion-promoting effects of chloride (Klausen et al., 2001). Sulfate, along with phosphate, molybdate, chromate, and silicate have been shown to inhibit arsenic removal by ZVI (Lackovic et al.,
2000; Su and Puls, 2001; Melitas et al., 2002), and silicate has also been shown to inhibit the degradation of TCE (Klausen et al., 2001; D'Andrea et al., 2005). Carbonate can temporarily increase the corrosion of ZVI, although carbonate solids passivate the reactive surface (Wieckowski et al., 1983; Gu et al., 1999; Köber et al., 2002; Klausen et al., 2003; Devlin and Allin, 2005).

Since contaminant removal depends on corrosion and the degree of corrosion is time-dependent, time-varying reaction rates for organic contaminants are commonly noted in batch and column studies, (e.g., Gillham and O’Hannesin, 1994; Agrawal and Tratnyek, 1996; Devlin et al., 1998; Klausen et al., 2003). In column studies, Farrell et al. (2000) reported that, in chloride and sulfate solutions, the half-life for trichloroethylene increased from 6.7 to $42 \mathrm{~h}$ after 667 days, whereas, in a nitrate solution, the half-life increased from 25 to $58 \mathrm{~h}$ over the same time frame. The removal of metals, however, tends to be fast and not as strongly dependent on time. For example, Köber and coworkers noted a temporal decline in reactivity towards 1,2-dichloroethylene, but no change in reactivity towards arsenic (Köber et al., 2005). Although recent work in the laboratory has begun to elucidate reaction mechanisms and kinetics, largely for organic contaminants, the kinetics of reactions in field conditions are not well characterized, due to the complexity of the system and the cost of monitoring. Therefore, it is difficult to accurately judge the degree of impact of media aging on treatment efficiency in the field.

\section{PRB failure modes}

To determine what factors influence PRB longevity in the field, performance data for PRBs were compiled and analyzed. Although there are over 200 PRBs operating, there was sufficient specific public information on field operating conditions and performance issues for only about 40. Utilizing this limited data base, three classes of possible failure modes of PRBs were delineated: loss of reactivity, adverse hydraulic changes, and design flaws. Each class may be subdivided, as presented graphically in Fig. 1. Although the emphasis in the literature has been placed on loss of reactivity and adverse hydraulic changes, it is design flaws that has been the most common cause of PRB failure (Warner and Sorel, 2003) and continues to be one of the main challenges to successful PRB implementation (ESTCP, 2003). Failure of in situ PRBs due to other modes appears to be rare. The only in situ PRBs that have reported operational failures that are not solely due to design flaws (e.g., inadequate hydraulic characterization) are at Monticello (UT) the Copenhagen Freight Yard (Denmark), and Haardkrom 


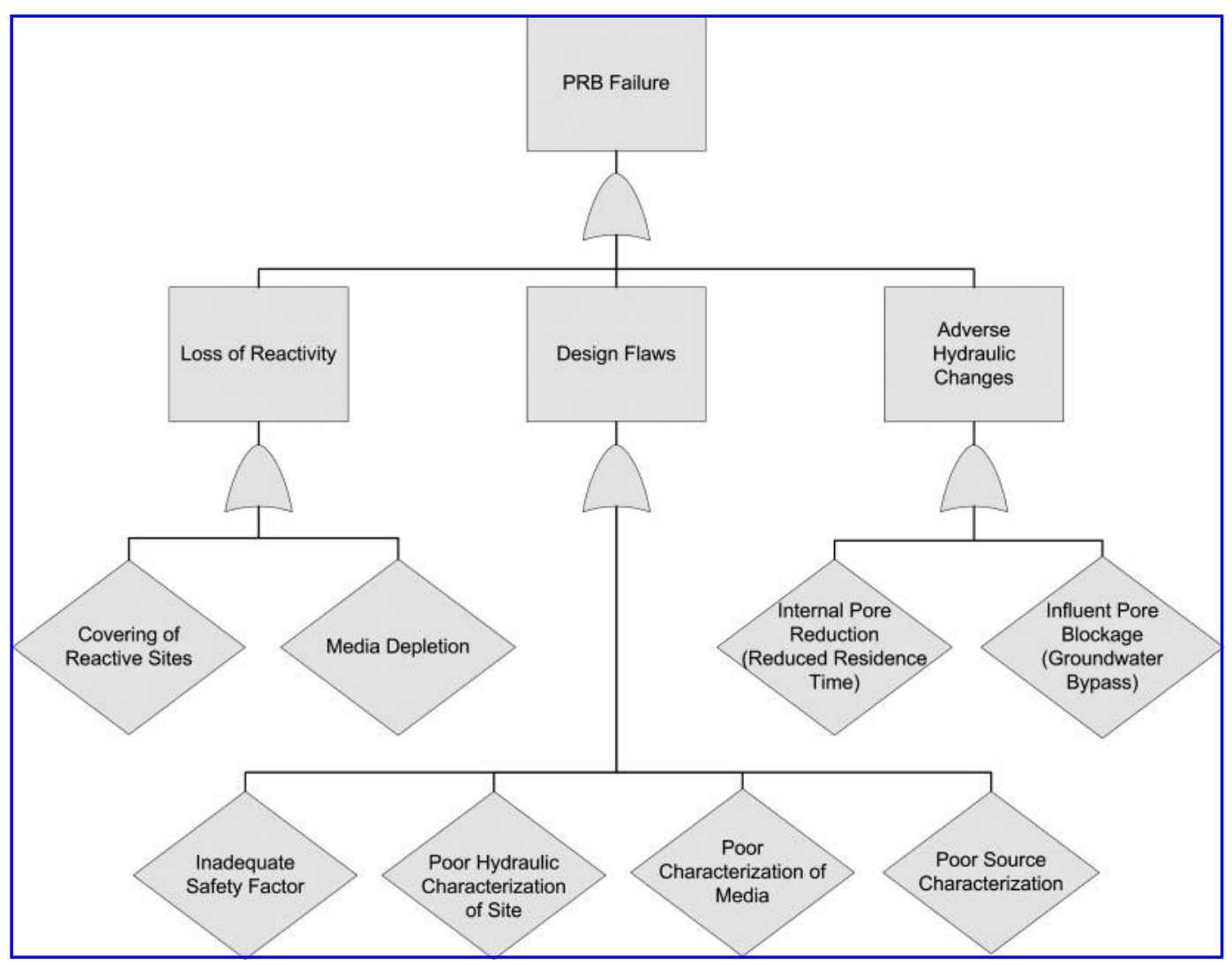

Figure 1. Fault tree showing events that contribute to PRB failure. Primary events (shown in diamonds) are combined with logical gates to create fault events (shown in rectangles) (McCormick, 1981).

(Denmark). The Monticello site experienced a hydraulic conductivity loss of three orders of magnitude (Mushovic et al., 2006). The Copenhagen Freight Yard reported loss of permeability due to precipitation of hydroxides and carbonates but also suffered from incomplete plume capture due to poor hydraulic characterization (Kiilerich et al., 2000; RTDF, 2001). The Haardkrom site's problems, however, are attributed to "exhaustion of iron-chromate removal capacity" with little more specific detail given (Kjeldsen and Fulgsang, 2000). Ex situ PRBs, on the other hand, tend to clog and fail with regularity: every site where ex situ reaction cells were installed has experienced clogging and failure of at least one of those cells [Hill AFB (UT), Portsmouth (Piketon, OR), UMTRA (Durango, CO), and Y-12 Pathway 1 [(Oak Ridge, TN)] (Shoemaker et al., 1995; Liang et al., 1997; Ott, 2000; Morrison et al., 2002b), with the exception of the ex situ PRB at Rocky Flats (Golden, CO) at which the crust forming on the reactive media was periodically broken up (Korte, 2001; RTDF, 2001).

Precipitation may also cause PRB failure by decreasing hydraulic residence times, leading to less effective treatment (Sass et al., 1998). In some cases, hydraulic short circuiting may occur, as preferential flow paths have developed in some column studies, (Kamolpornwijit et al., 2003; Su and Puls, 2003), and some evidence exists for their occurrence in the field (Liang et al., 2003). However, no performance changes have yet been attributed to reduced residence time. Some sites did not reach treatment goals (e.g., Borden, Ontario), and sometimes incomplete degradation occurred (e.g., CSM, Australia), but these problems were design flaws (i.e., present at installation) and were not due to porosity reduction.

Adverse hydraulic changes may also be caused by gas formation or biomass accumulation. According to Equation (4), hydrogen gas may be produced and the production of other gases is possible; for example, methane was reported at the in situ PRB at Copenhagen Freight Yard (Denmark) (Kiilerich et al., 2000) and at the ex situ cell $\mathrm{C}$ at the UMTRA site (Durango, CO) (Morrison et al., 2002c), presumably from the activity of methanogenic bacteria. Ex situ PRBs and laboratory studies, which are confined systems, frequently report plugging due to gas production [e.g., Portsmouth (OR) and UMTRA (Durango, CO)] (Korte et al., 1997a; Mackenzie et al., 1999; Morrison et al., 2002b). However, none of the in situ 
PRBs report porosity reduction due to gas production, suggesting that any gas that is formed is able to migrate out of the barrier. Similarly, biomass-related hydraulic changes have been observed in some laboratory studies (e.g., Taylor et al., 1990; Vandevivere and Baveye, 1992) but do not seem to be an issue in the field. Microbial growth was minimal at Intersil (Sunnyvale, CA), Moffett Field (Mountain View, CA), Industrial Site (NY), Lowry AFB (CO), and Somersworth (NH) (Gu et al., 1999), and although observed at locations like USCG (Elizabeth City, NC) and Denver Federal Center (CO), it did not impact performance, perhaps because biofouling is unlikely at the high $\mathrm{pH}$ and low $E_{H}$ values often observed in ZVI PRBs (Liang et al., 2000).

\section{OBJECTIVES}

Since few in situ PRBs have failed due to other than design flaws, it is difficult to determine factors controlling longevity by looking at failure rates. Rather, the existing information must be analyzed for factors that place a PRB "at risk," defined as an increased likelihood of compromised performance, based on reports of a decrease in permeability or in contaminant removal. In ZVI PRBs, high concentrations of dissolved solids, dissolved oxygen, carbonate, nitrate, and/or sulfate are expected to favor media corrosion and solids precipitation. This tendency would be exacerbated at high $\mathrm{pH}$ or low $E_{H}$. For example, to quantify the likelihood of precipitation, Liang et al., (2003) argued that the saturation indices (SI) for calcite and iron (oxyhydr)oxides, defined as the difference between the actual $\mathrm{pH}$ and the $\mathrm{pH}$ at which solution ions would be in equilibrium with a solid phase $\left(\mathrm{SI}=\mathrm{pH}_{\text {actual }}-\mathrm{pH}_{\text {equilib }}\right)$ (Köber et al., 2002), may be a suitable parameter for predicting clogging, and thus reduced longevity. Using this approach, severe clogging over a 10-year period was predicted at the Monticello (UT) PRB, and, indeed, this PRB experienced a hydraulic conductivity loss of three orders of magnitude four years after installation (Mushovic et al., 2006).

The objective of this research is to analyze the geochemical and performance data from existing in situ ZVI PRBs and determine whether certain geochemical parameters can indeed indicate a potential for reduced PRB longevity. In particular, three categories of parameters were considered: (1) master variables like $\mathrm{pH}$ and $E_{H}$, (2) parameters related to the quantity of precipitation [these precipitation parameters include total dissolved solids, dissolved oxygen and the concentrations, mass fluxes and cumulative fluxes of individual solutes (e.g., $\mathrm{CO}_{3}{ }^{2-}$, $\mathrm{Ca}^{2+}$ ), and saturation indices]; and (3) parameters relating to reactivity promotion or inhibition (e.g., anions like
$\mathrm{NO}_{3}{ }^{-}$and $\mathrm{Cl}^{-}$). It is recognized that these categories of parameters are not mutually exclusive: $\mathrm{pH}$ affects carbonate speciation, carbonate affects iron reactivity, etc.

\section{METHODS}

Because of the limited comprehensive geochemical data available in the literature, the quantitative analysis was, of necessity, confined to $16 \mathrm{ZVI}$ in situ field PRBs treating organics and/or metals for which extensive information was available (Table 3). Ex situ barriers were not included in the analysis, for they clearly operate under different conditions than in situ barriers, rendering them more prone to failure. Based on information provided in the literature and geochemical principles, $37 \mathrm{pa}-$ rameters were selected for consideration (Tables 4 and 5). Frequently, ranges of values, or values from several sampling events, or values from different monitoring wells were reported for a given parameter at a particular PRB. To distill this information to a single data point for the analysis, an arithmetic mean was used for all parameters except hydraulic conductivity, hydraulic gradient, and flow rate. Reported values of these parameters frequently ranged over several orders of magnitude, so a geometric mean was used. In some cases, geochemical parameters such as total dissolved solids and alkalinity were not reported and were calculated from the available information. Sites were assigned a 0 or 1 indicating failure, or 0 or 1 indicating at risk if a loss in permeability, a loss in reactivity, or some other indication of compromised performance was reported. The collated data are presented in Table 4 and the calculated parameters in Table 5.

Both graphical and statistical analyses were conducted to determine which geochemical parameters are correlated with potential decreased longevity. As a first cut, the data were plotted to give a rough indication as to whether the particular parameter had any relation to classifying PRBs as at risk. Statistical analyses included an assessment for collinearity, univariate and multivariate logistic regression, and maximization of odds ratios. The degree of linear correlation for all parameter combinations was calculated using the SPSS statistical software package (SPSS Inc., Chicago, IL). The sample correlation coefficient, also know as Pearson's correlation, is defined as (Myers, 1990):

$$
r=\frac{S_{x y}}{\sqrt{S_{x x} S_{y y}}}
$$

where $S$ is the residual sum of squares (either for the interaction of 2 variables or each variable singly). Variables found to be correlated at the $95 \%$ confidence level 


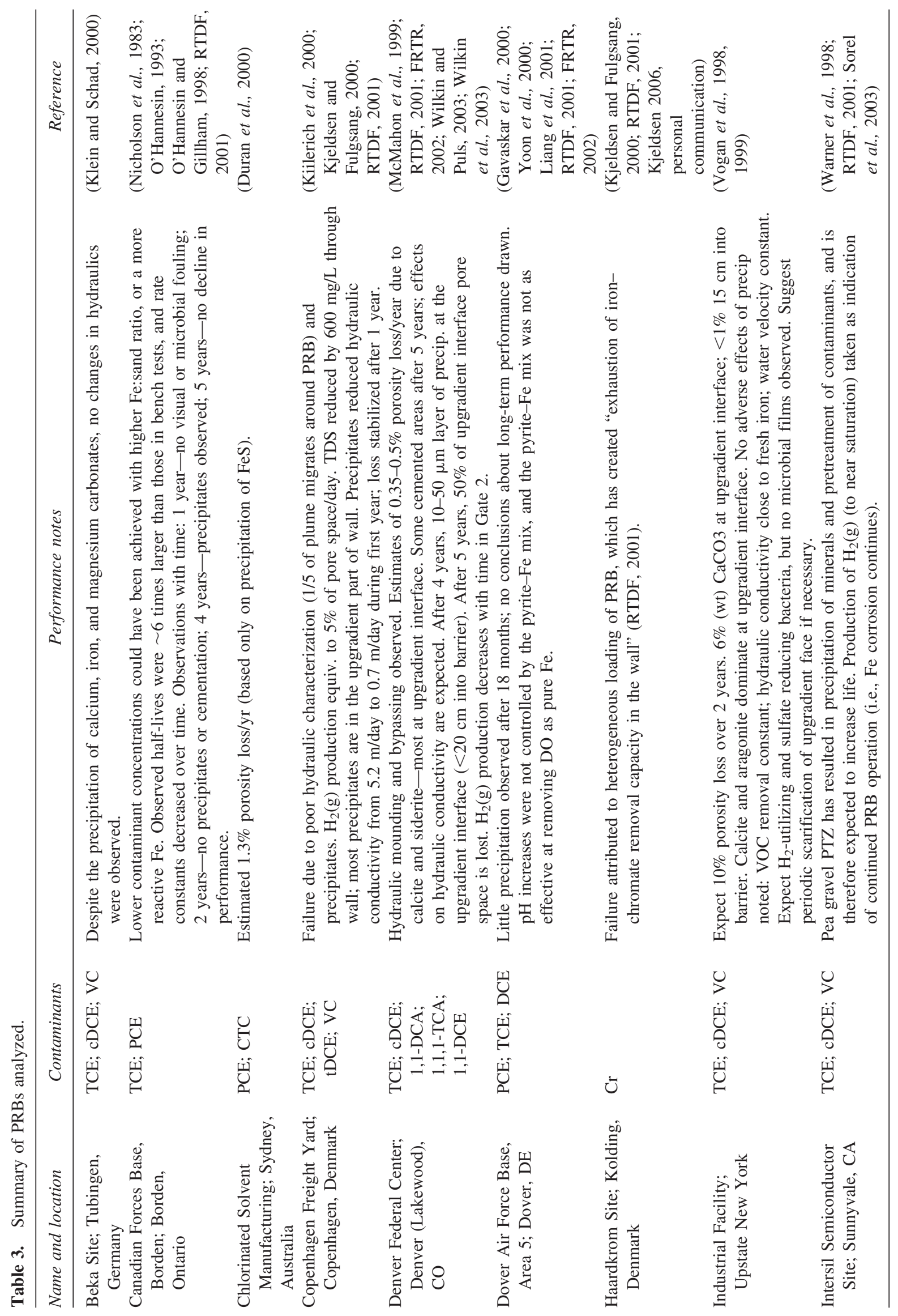




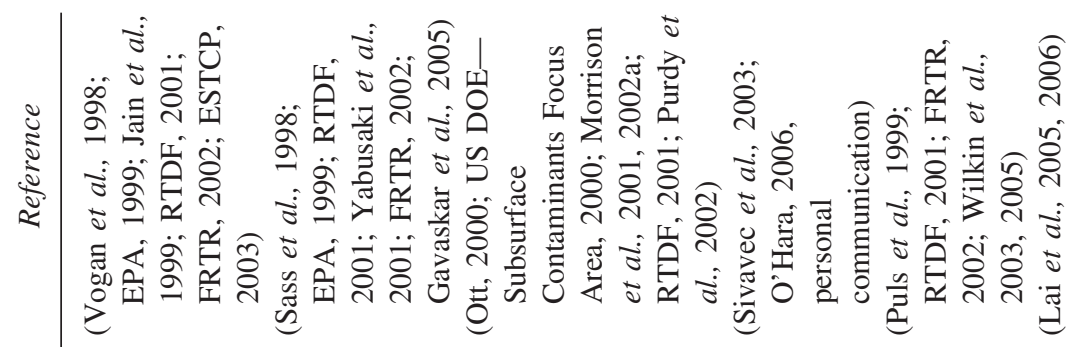

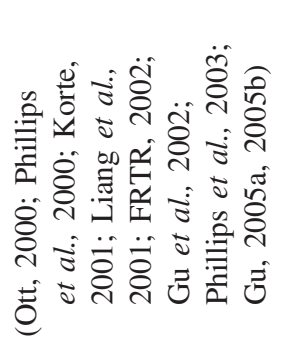

है

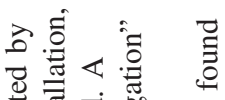

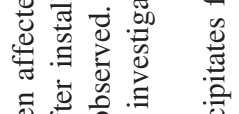

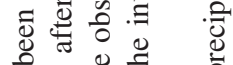

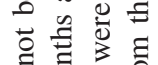

글

西 $\infty$ :

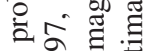

可

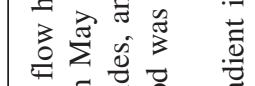

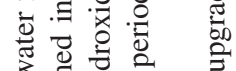

ำ

웡

空定

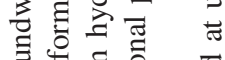

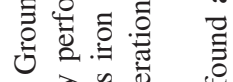

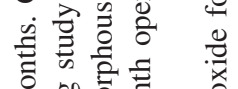

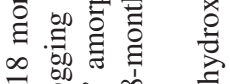

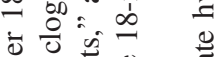

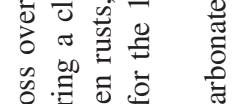

궁ํำ

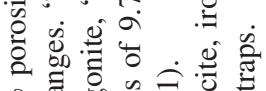

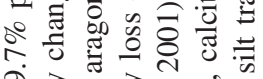

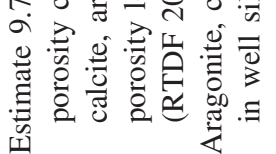

颉

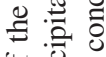

楁:

离合焉

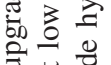

穿.

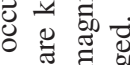

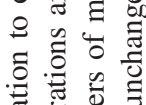

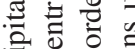

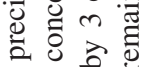

言足总

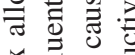

肴要吅

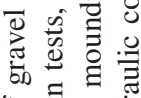

的的

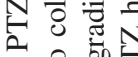

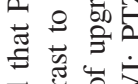

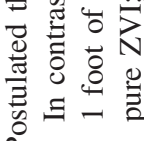

ป

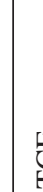

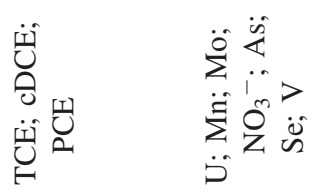

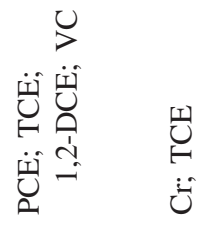

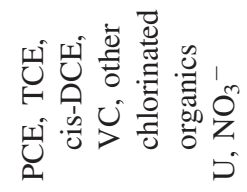

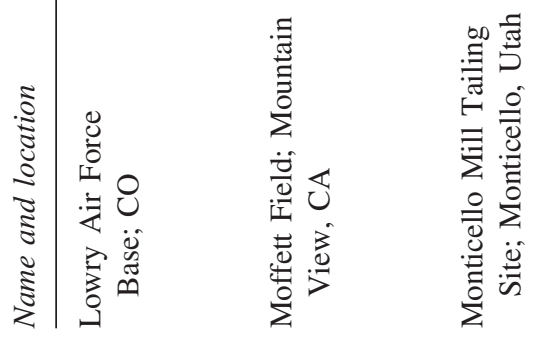

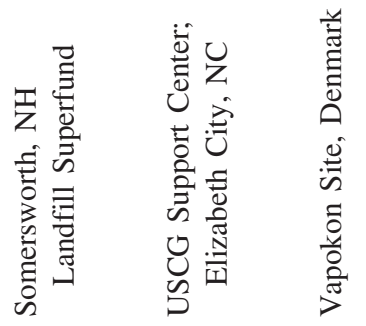

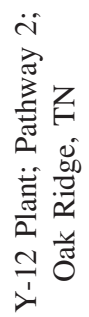




\begin{tabular}{|c|c|c|c|c|c|c|c|c|c|c|c|c|c|c|c|}
\hline 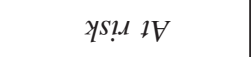 & 00 & 0 & - & - & 0 & - & 0 & 0 & 0 & $0-$ & 0 & 0 & - & - & 2.0 \\
\hline a.ı१! $p_{H}$ & 00 & 0 & 0 & 0 & 0 & - & 0 & 0 & 0 & $0-$ & 0 & 0 & 0 & 0 & \\
\hline 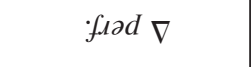 & 00 & 0 & 0 & 0 & 0 & - & 0 & 0 & 0 & $0-$ & 0 & 0 & 0 & - & \\
\hline : «К & 00 & 0 & - & - & 0 & 0 & 0 & 0 & 0 & $0-$ & 0 & 0 & - & - & \\
\hline$Z L d$ & -0 & 0 & - & - & - & 0 & - & - & 0 & -- & 0 & 0 & - & - & \\
\hline $\begin{array}{c}(7 / \delta m) \\
\text { เนวпๆรu! -1D }\end{array}$ & $\cong N$ & | & $\infty$ & ?ִ & $\stackrel{ల}{ }$ & I & 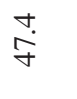 & 1 & 8 & $\hat{\dot{q}} \tilde{\underline{C}}$ & $\stackrel{m}{+}$ & q & $\stackrel{0}{\dot{b}}$ & ñ & \\
\hline 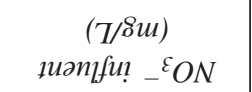 & $r \stackrel{0}{0}$ & | & $\tilde{3}$ & 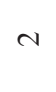 & $\infty$ & $\stackrel{+}{\dot{m}}$ & $\overline{3}$ & I & $\nabla$ & $\stackrel{+}{i} \stackrel{\infty}{=}$ & $?$ & $\exists$ & | & $\infty$ & \\
\hline $\begin{array}{c}(7 / \delta i u) \\
\text { циวтlfu! } z^{\dagger} O S\end{array}$ & $\infty$ o्ठి & $\stackrel{2}{2}$ & $\stackrel{\varrho}{\varrho}$ & $\stackrel{8}{\circ}$ & $\dddot{2}$ & $n$ & $\stackrel{n}{=}$ & \& & 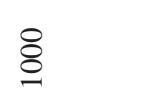 & 유로 & $\dot{\vec{g}}$ & qे & 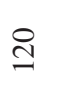 & $\tilde{n}$ & \\
\hline 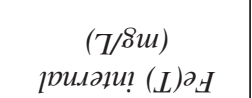 & ñ? & ¿े & $\tilde{o}$ & $\stackrel{+}{0}$ & $\because$ & กั & $\stackrel{0}{0}$ & $\stackrel{2}{0}$ & 1 & $\frac{1}{0} \div$ & $\stackrel{0}{\circ}$ & $\stackrel{n}{0}$ & $n$ & $\stackrel{g}{\dot{I}}$ & \\
\hline 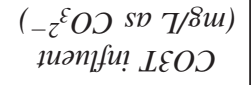 & t우오 & छ & స్ర & : & さे & I & $\stackrel{\circ}{m}$ & $\overline{\mathrm{i}}$ & $\stackrel{n}{2}$ & \&̊ & 8 & 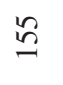 & สิ & ¿ & \\
\hline 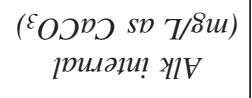 & $=\underset{\infty}{i}$ & $\mathscr{\infty}$ & ঐे & ஜn & $\frac{\sigma}{\forall}$ & $\stackrel{\infty}{\infty}$ & تే & $\stackrel{\leftrightarrow}{\sim}$ & | & तึં & $\stackrel{n}{=}$ & $\stackrel{\dot{\infty}}{\infty}$ & ?ִ & $\stackrel{\infty}{\infty}$ & \\
\hline 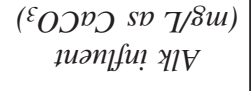 & m & $\stackrel{m}{n}$ & 官 & f & 0 & $\bar{\beth}$ & ते & $\tilde{\text { }}$ & in & $\stackrel{\infty}{\infty} \underset{\sim}{\sim}$ & $\stackrel{\infty}{m}$ & in & $\frac{\Delta}{m}$ & : & \\
\hline 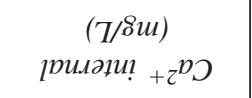 & ণิ ชิ & I & $\stackrel{\circ}{\infty}$ & $\hat{i}$ & $\stackrel{\circ}{\circ}$ & $n$ & $\stackrel{\circ}{\circ}$ & I & | & $\stackrel{\grave{O}}{\bar{v}}$ & $\underset{n}{n}$ & nis & $\stackrel{\grave{i}}{\text { r }}$ & $n$ & \\
\hline $\begin{array}{c}(7 / \delta i u) \\
\not и ə \eta \mid f u !+z^{b \supset}\end{array}$ & 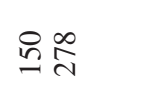 & I & అి & ఏ & $\dddot{f}$ & $\ddot{n}$ & ஜே. & | & ঐे & $\stackrel{\infty}{n}$ ले & ci & $\stackrel{n}{\mathfrak{c}}$ & 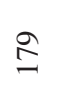 & ఏ & \\
\hline $\begin{array}{c}(7 / \delta u) \\
\text { นиวэ|fu! } O Q\end{array}$ & $\stackrel{\circ}{-} \stackrel{+}{\oplus}$ & $\stackrel{\circ}{\circ}$ & ֻั & $\stackrel{5}{0}$ & $\stackrel{\sim}{\sim}$ & in & | & $\stackrel{\circ}{i}$ & $\stackrel{0}{0}$ & ت̊: & $\stackrel{\circ}{i}$ & $\exists$ & $\stackrel{\oplus}{m}$ & $\stackrel{\infty}{i}$ & \\
\hline $\begin{array}{c}(7 / \delta m) \\
\text { เиวпๆfu! } S G L\end{array}$ & 8 & $\hat{\&}$ & ปี & $\stackrel{8}{\Xi}$ & 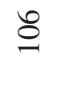 & స్ల & $\stackrel{\infty}{\stackrel{े}{\sigma}}$ & $\mathscr{\infty}$ & ঃ & స్ & \& & ঐ) & $\stackrel{i}{2}$ & $\infty$ & \\
\hline $\begin{array}{c}\left(\Lambda^{u)}\right) \\
\text { рицวци! }{ }_{\text {H马 }}\end{array}$ & 을 & $\stackrel{\bar{T}}{i}$ & | & $\frac{2}{1}$ & 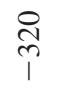 & | & $\stackrel{\text { अे }}{1}$ & के & 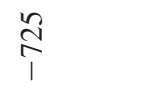 & $\underset{i}{N} i_{\substack{\infty \\
\infty}}^{\infty}$ & $\stackrel{R}{i}$ & $\underset{1}{\&}$ & $\stackrel{m}{i}$ & $\stackrel{8}{1}$ & \\
\hline риияәчи! $H^{d}$ & $\overrightarrow{0} \infty$ & $\stackrel{\circ}{r}$ & $\ddot{\sigma}$ & $\hat{a}$ & $\stackrel{\infty}{\varrho}$ & $\stackrel{n}{0}$ & 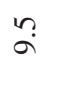 & $\stackrel{n}{0}$ & $\stackrel{\circ}{\circ}$ & $\because \circ$ & $\stackrel{0}{0}$ & $\stackrel{\infty}{\sigma}$ & $\stackrel{\infty}{\sigma}$ & $\stackrel{\circ}{\circ}$ & \\
\hline циวпџรи! $H^{d}$ & $\vec{\pi}$ & $\stackrel{\odot}{+}$ & $\stackrel{r}{r}$ & $\stackrel{n}{n}$ & $\bar{n}$ & $\stackrel{i}{\infty}$ & $\stackrel{+}{r}$ & $\stackrel{\infty}{\sim}$ & $\hat{\sigma}$ & तथ & $\tilde{n}$ & $\overrightarrow{6}$ & $\stackrel{n}{2}$ & $\hat{b}$ & \\
\hline 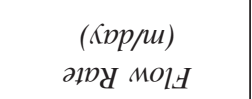 & $\begin{array}{ll}n \\
0 \\
0\end{array}$ & $\begin{array}{l}: \\
\stackrel{8}{0}\end{array}$ & $=$ & $\stackrel{0}{0}$ & $\stackrel{n}{i}$ & $\underset{8}{\varnothing}$ & $\stackrel{\text { nf }}{0}$ & $\tilde{n}$ & ֻ̊. & 䔻 in & oे & $\dddot{f}$ & $\hat{\jmath}$ & 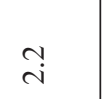 & \\
\hline $\begin{array}{c}(.\lrcorner р ә К) \\
\text { วu! } L \text { ипу }\end{array}$ & NO & - & $m$ & $r$ & $\nabla$ & $\sim$ & 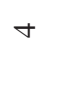 & $\infty$ & & $a m$ & $ナ$ & $\infty$ & $r$ & 6 & \\
\hline § & 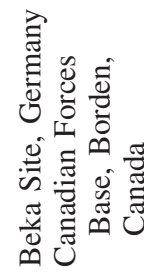 & 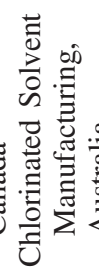 & & & & 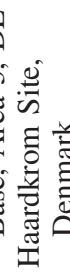 & 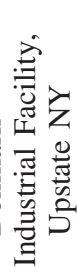 & 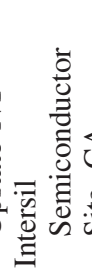 & 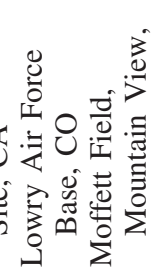 & 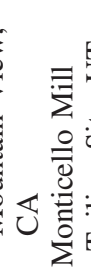 & & & 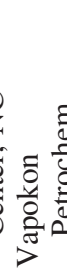 & 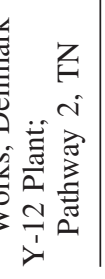 & \\
\hline
\end{tabular}




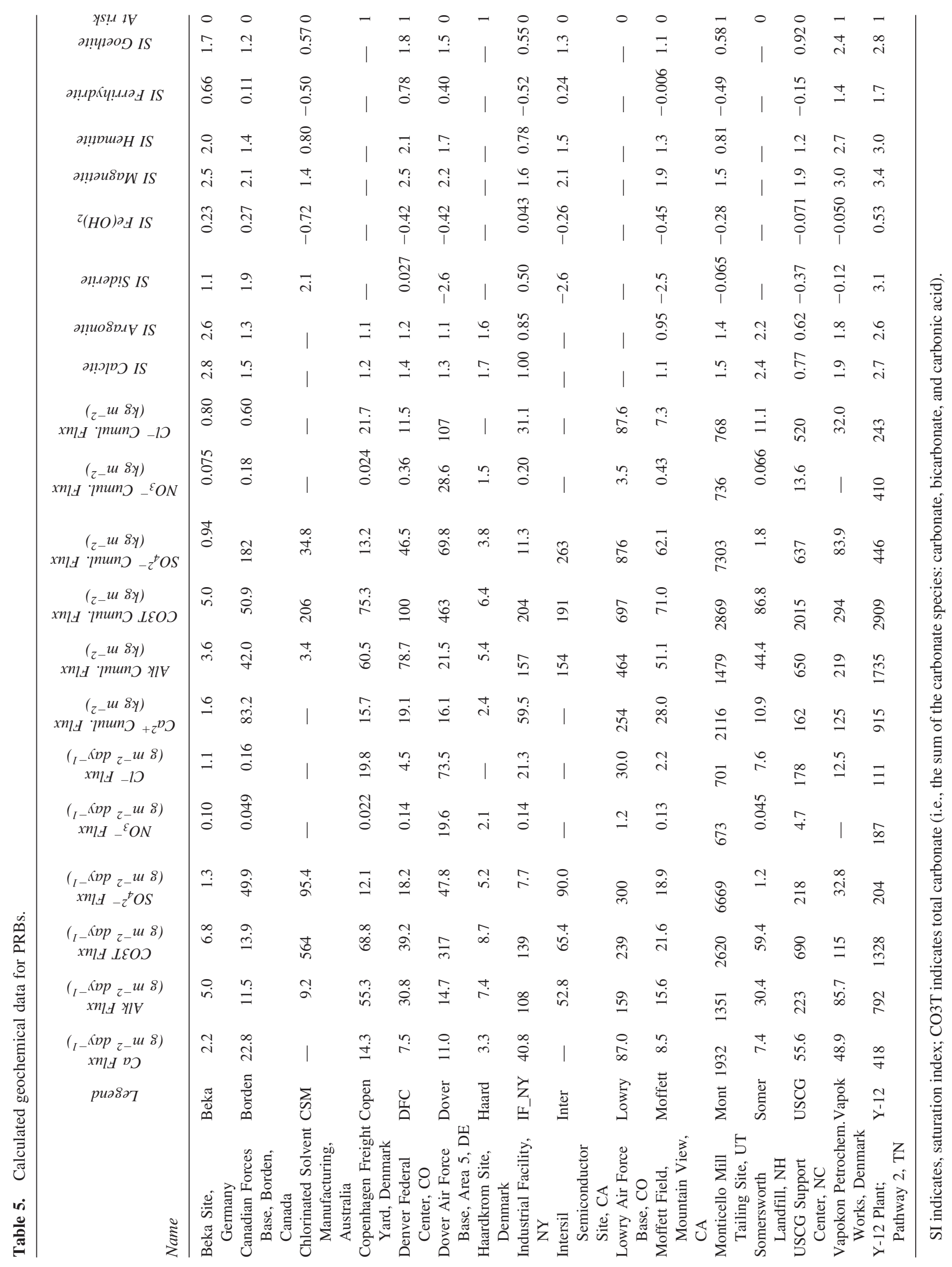


were discarded. Then, univariate logistic regression was carried out, following the approach outlined in Hosmer and Lemeshow (1989), using the SPSS software package. For the vector $\mathbf{x}$, a set of independent, predictor variables (the geochemical parameters), the conditional probability, $\pi(\mathbf{x})$, of a dependent variable outcome of at risk can be calculated from:

$$
\pi(\mathbf{x})=\frac{\exp (g(\mathbf{x}))}{1+\exp (g(\mathbf{x}))}
$$

using a linear predictor, $g(\mathbf{x})$, with coefficients $\beta_{i}$ :

$$
\begin{array}{r}
g(\mathbf{x})=\beta_{0}+\beta_{1} x_{1}+\beta_{2} x_{2}+\ldots+\beta_{p} x_{p} \\
+\ldots+\varepsilon
\end{array}
$$

where $\varepsilon$ accounts for variations that are not covered by terms in the model. If the logistic regression considers only one variable, then this linear predictor reduces to $g(\mathbf{x})=$ $\beta_{0}+\beta_{1} x_{1}+\varepsilon$. Continuously scaled variables (such as influent alkalinity), binary variables (such at the use of a pretreatment zone), and combinations of variables may all be included in $g(\mathbf{x})$. The coefficients $\beta_{i}$ are calculated through regression between the independent predictor variable vector $\mathbf{x}$ and $g(\mathbf{x}) . g(\mathbf{x})$ is determined using Equation (7), assuming that $\pi(\mathbf{x})$ may be calculated as:

$$
\pi(\mathbf{x})=P(\text { at_risk } \mid \mathbf{x})
$$

where an estimate of $P($ at_risk $\mid \mathbf{x})$ is based on counts of PRBs that are at risk and those which are not (Hosmer and Lemeshow, 1989; Faraway, 2006).

In estimating each value of $\beta_{i}$, a standard error (SE) is estimated, and thus, the Wald statistic $\left(\mathrm{Wald}_{i}=\right.$ $\beta_{i} /$ S.E. $\left.\left(\beta_{i}\right)\right)$ may be calculated. The Wald statistic tests the null hypothesis that $\beta_{i}=0$; if the significance (or $p$ value) associated with the regression is acceptably small (e.g., $\leq 0.25$ ), it may be assumed with the associated confidence level (for $p \leq 0.25$, this confidence level is $75 \%$ ) that the null hypothesis may be rejected, and thus, the estimate of $\beta_{i}$ is equivalent to $\beta_{i}$. Based on the recommendation of Hosmer and Lemeshow (1989), variables with significance $\leq 0.25$ were considered further.

In addition to logistic regression, odds ratio maximization was used to identify geochemical parameters with a strong relationship to at-risk PRBs. The odds ratio estimates how much more likely it is for a certain out- come (e.g., at risk) given an input (e.g., influent alkalinity concentration above a specified value). The odds ratio can be expressed as (Hosmer and Lemeshow, 1989)

$$
\psi=\frac{\pi(1) /(1-\pi(1))}{\pi(0) /(1-\pi(0))}
$$

where $\pi(1)$ is the probability of being at risk, and $\pi(0)$ is the probability of being not at risk.

If $\pi(\mathbf{x})$ is not known, the probabilities may be estimated with a contingency table, a $2 \times 2$ matrix that shows, for each possible outcome, the number of cases with each independent variable. For example, consider the parameter influent alkalinity concentration or Alk_inf (Table 4). If $300 \mathrm{mg} / \mathrm{L}$ is defined as the cutoff value, then of the PRB sites with Alk_inf $\geq 300 \mathrm{mg} / \mathrm{L}, 4$ are at risk, and 3 are not at risk. Similarly, the cases with Alk_inf $<$ $300 \mathrm{mg} / \mathrm{L}$ are divided into 2 at risk and 7 not at risk, yielding the contingency table shown in Table 6 . The estimated odds ratio is then $(4 / 3) /(2 / 7)$, or 4.67 . This result indicates that, for this dataset, sites with Alk_inf $\geq 300$ $\mathrm{mg} / \mathrm{L}$ are 4.67 times more likely to be at risk than those with lower Alk_inf.

The selection of a cutoff value is integral to the calculation of an odds ratio. In this study, the odds ratio for each parameter was maximized. Cutoff values for each parameter were systematically varied over 100 steps between the minimum and maximum values for that parameter, and the maximum odds ratio was recorded. A perfect predictor, a cutoff below which all sites were not at risk and above which all sites were at risk, would lead to the recording of zero values in the off-diagonal in the contingency table, and thus a value of zero in the denominator of Equation (10). In those cases, the zero value was replaced with 0.5 , as recommended by Hosmer and Lemeshow (1989). To evaluate the importance of the calculated odds ratios, significance values were computed using the two-sided Fisher Exact test. This test, a form of the chi-square evaluation, is appropriate for sparse datasets and evaluates whether the tested variables are independent or associated (Faraway, 2006). In the current study, a significance ( $p$-value) of 0.05 was used as the criterion for inclusion of variables for further consideration.

Finally, those parameters selected by the univariate logistic regression based on a significance $\leq 0.25$ or an odds

Table 6. Example of contingency table using a cutoff value for influent concentration of alkalinity of $300 \mathrm{mg} / \mathrm{L}$.

\begin{tabular}{lcc}
\hline Total $=16$ & Alk_inf $\geq 300 \mathrm{mg} / \mathrm{L}$ & Alk_inf $<300 \mathrm{mg} / \mathrm{L}$ \\
\hline At risk & 4 & 2 \\
Not at risk & 3 & 7 \\
\hline
\end{tabular}


ratio Fisher Exact test significance $\leq 0.10$ were incorporated into a multivariate logistic regression model. These variables were then used together in logistic regression [Eqs. (7-9)] in an attempt to judge the relative significance of the variables in determining longevity potential.

\section{RESULTS AND DISCUSSION}

\section{Graphical analysis}

To determine which geochemical parameters correlate with compromised PRB performance, matrix plots of all the variables were constructed, an example of which is shown in Fig. 2. In this figure, PRBs classified as at risk are indicated by diamonds, while those PRBS not at risk are indicated by circles. Regions in these two-dimensional geochemical spaces where PRBs at risk and those not at risk tend to group may be indicative of important geochemical parameters; lack of grouping is suggestive of little correlation. For example, this figure suggests that dissolved oxygen (DO) and total dissolved solids (TDS) (shown enlarged in Fig. 3), although expected to strongly influence PRB performance based on the literature, do not do so. Column studies and theoretical calculations have clearly shown the possibility of deleterious effects of DO on barrier hydraulics (Liang et al., 1997; Mackenzie et al., 1999; Kjeldsen and Fulgsang, 2000; Ott, 2000;

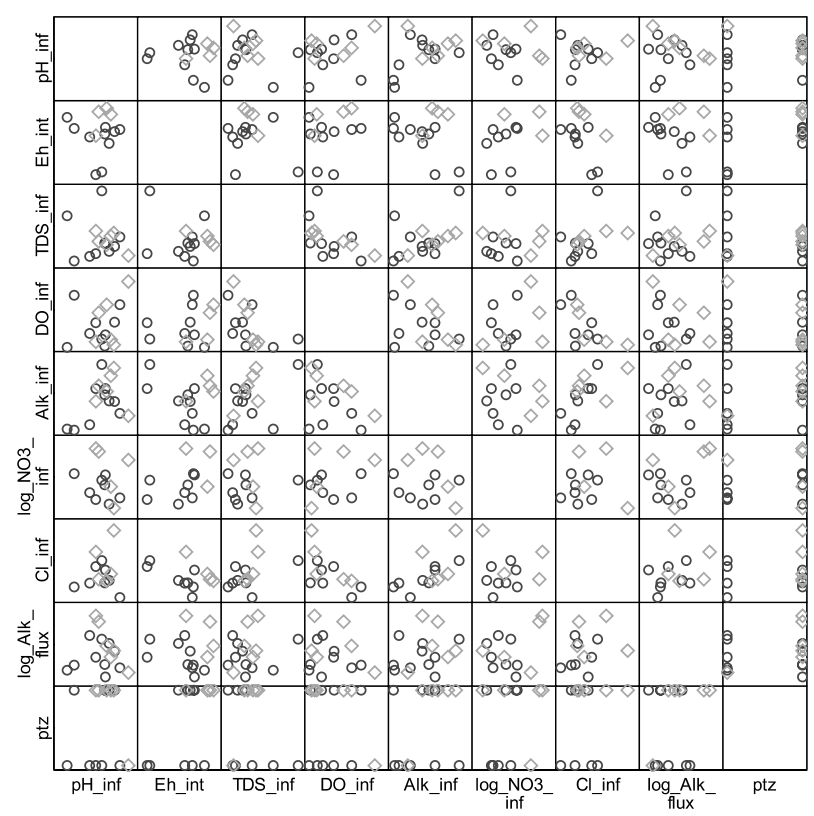

Figure 2. Matrix plots of selected geochemical parameters. At-risk PRBs are indicated by diamond markers, not-at-risk by circles. Units are $(\mathrm{mg} / \mathrm{L})$ except for $\mathrm{E}_{\mathrm{H}}(\mathrm{mV})$ and ptz (1 indicates use of a pretreatment zone).
Simon et al., 2001; Morrison et al., 2002b). DO is expected to corrode iron, increase $\mathrm{pH}$, and promote the formation of (oxyhydr)oxide solids. If influent DO were a controlling factor, at risk PRBs should be grouped above some cutoff DO value. Yet Fig. 3a shows at-risk PRBs at extremely low DO values, suggesting that DO is not well correlated with PRB longevity.

Similarly, based on the literature, it seems likely that TDS is a good estimator of potential failure: high influent TDS concentrations generally lead to high quantities of mineral precipitation (Gillham et al., 1993; Gu et al., 1999; ESTCP, 2003; Wilkin and Puls, 2003). However, as seen in Fig. 3b, there are several PRB sites with high TDS that are not at risk. If solutes such as $\mathrm{Na}^{+}$account for a large portion of the dissolved solids, TDS may not be a reliable indicator of the potential for precipitation.

Besides suggesting parameters that may not correlate with the potential for reduced longevity, these matrix plots indicated other parameters that might be related to at-risk PRBs. Perhaps most evident were very high fluxes and cumulative fluxes of influent alkalinity, as well as influent concentrations and cumulative fluxes of nitrate (Fig. 4). Although these outliers were few in number, the extreme values appear to be strongly correlated with atrisk PRBs. Monticello (UT) and Y-12 (Oak Ridge, TN) PRBs have very high mass fluxes and cumulative fluxes for alkalinity and nitrate (as well as total carbonate and calcium); these PRBs are also classified as at risk. This finding makes conceptual sense, as exceptionally high mass loadings increase the possibility of high levels of precipitation (Wilkin and Puls, 2003). In addition, nitrate has been shown to inhibit corrosion (e.g., Köber et al., 2002; Devlin and Allin, 2005). In most PRBs, nitrate values are generally quite low; only Monticello, Y-12, and Haardkrom (Denmark) have values above $10 \mathrm{mg} / \mathrm{L}$, and of these three, two, Monticello and Haardkrom, have actually failed.

This analysis of the matrix plots also indicated some combinations of parameters that may be correlated with at-risk PRBs, including internal $E_{H}$, influent alkalinity, influent chloride concentrations, and the saturation indices of iron(III) solids. Two example plots are shown in Fig. 5. Figure 5a shows a complete separation of at-risk and not-at-risk PRBs using internal $E_{H}$ and influent chloride concentration. In the upper right section of the graph, the at-risk PRBs are found, while the not-at-risk PRBs lie below and to the left. This PRB grouping makes sense: higher $E_{H}$ values may lead to more oxidation and thus more potential passivation of iron (Stumm and Morgan, 1996; Johnson et al., 1998; Wilkin and Puls, 2003). Chloride has been shown to increase corrosion of iron (Johnson et al., 1998; Devlin and Allin, 2005), which would be expected to improve PRB performance; however, 
a)

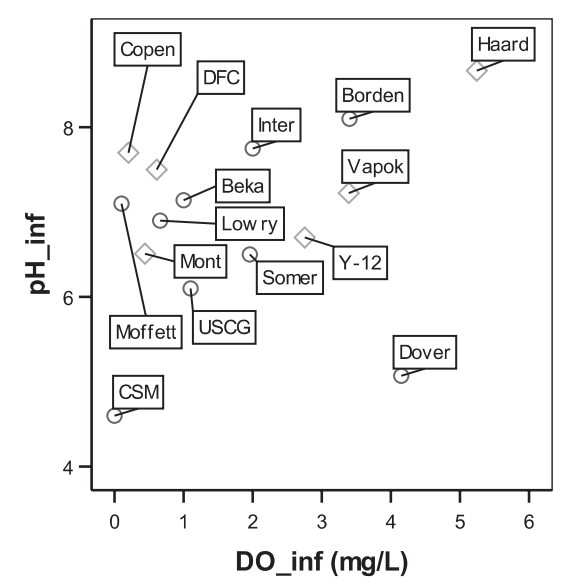

b)

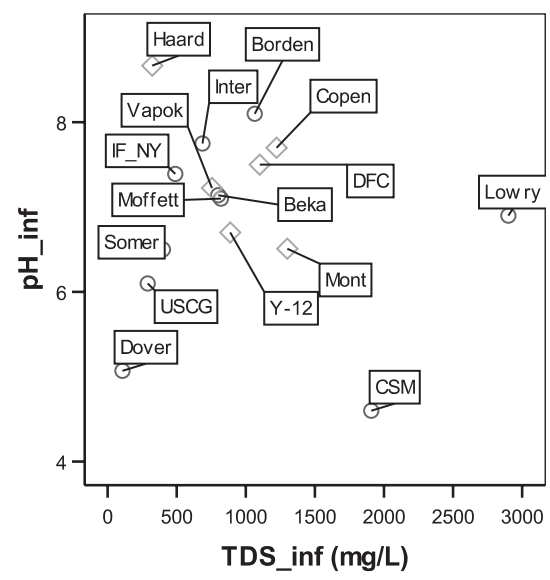

Figure 3. Plot of at-risk and not-at-risk PRBs with respect to influent $\mathrm{pH}$ and (a) influent DO, (b) influent TDS. At-risk PRBs are indicated by diamond markers, not-at-risk by circles.

Klausen et al., (2001) showed that the reactivity-diminishing effects of nitrate may outweigh the corrosion-promoting effects of chloride. Figure 5b shows the data set plotted as a function of influent alkalinity and nitrate concentration. Although the separation of at-risk and not-atrisk PRBs is not as definitive as in Fig. 5a, Fig. 5b still suggests that higher alkalinity and higher $\mathrm{NO}_{3}{ }^{-}$concentrations correlate with being at risk. The PRB at Lowry AFB (CO), with low nitrate and high alkalinity, is an ex-

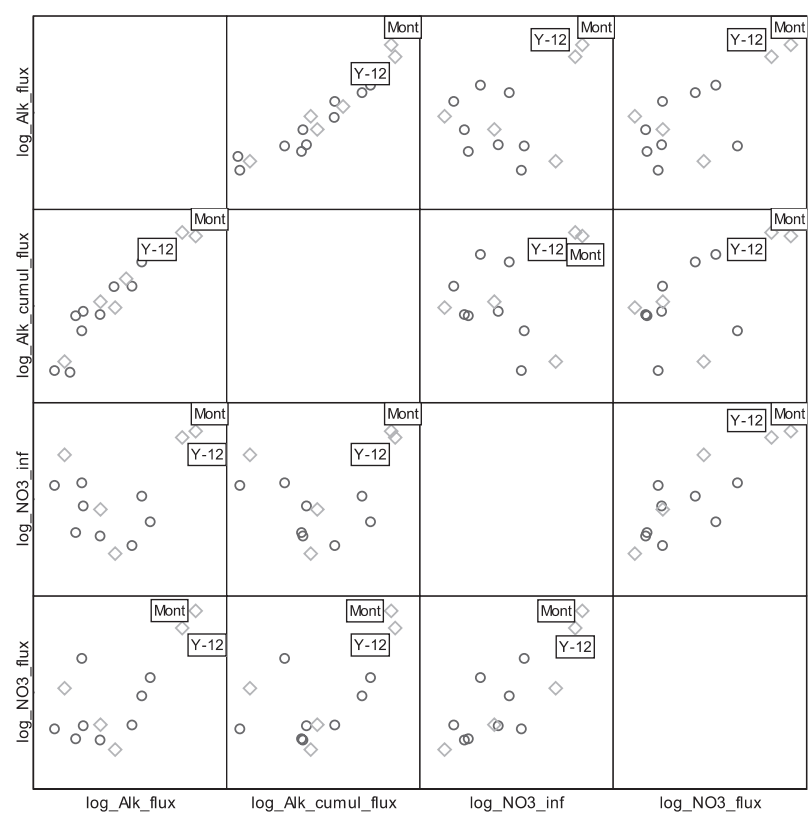

Figure 4. Significance of very high alkalinity and nitrate for prediction of at-risk PRBs. At-risk PRBs are indicated by diamond markers, not-at-risk by circles. ception to this trend, but considering Fig. 5a, this may be attributable to its very low $E_{H}$ value.

Finally, the matrix plots of the data indicated that many of the parameters, especially mass fluxes, cumulative fluxes, and saturation indices are strongly correlated with one another. The high degree of collinearity between mass fluxes $\left(\mathrm{g} \mathrm{m}^{-2} \mathrm{day}^{-1}\right)$ and cumulative fluxes $\left(\mathrm{kg} \mathrm{m}^{-2}\right)$ (Fig. 6) suggests that variation in the flow rate dominates the parameter value rather than the variation in concentration. Similarly, the saturation indices of hematite, ferrihydrite, and goethite, all iron(III) species, and magnetite, an iron(II)/iron(III) solid, are collinear. This relationship stems from the fact that at the $E_{H}$ values in the PRBs in this data set, aqueous iron(III) concentrations are negligible. Iron (III) concentrations may be calculated from reported values of iron (II), but it will be directly proportional to the reported $E_{H}$ values. Because the saturation indices of these solids will vary with the aqueous iron(III) concentrations, all are collinear.

\section{Statistical analyses}

To assess the degree of collinearity in the data, a Pearson correlation test was conducted. The results showed that three sets of variables had correlations significant at the $95 \%$ confidence level: (1) flow rate, mass fluxes, and cumulative fluxes; (2) the saturation indices of calcite and aragonite; and (3) $E_{H}$ with saturation indices of iron(III) solids. Based on this analysis, it was deemed necessary only to include only one flux, one calcium carbonate solid, and one member of the third set. Based on its potential to diminish the hydraulic conductivity and reactivity of ZVI PRBs, the mass flux of alkalinity was chosen in the first category; calcite was chosen as the calcium carbonate 
a)

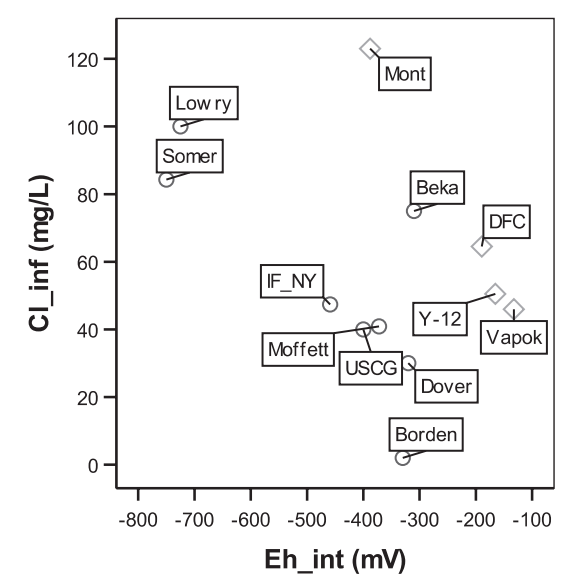

b)

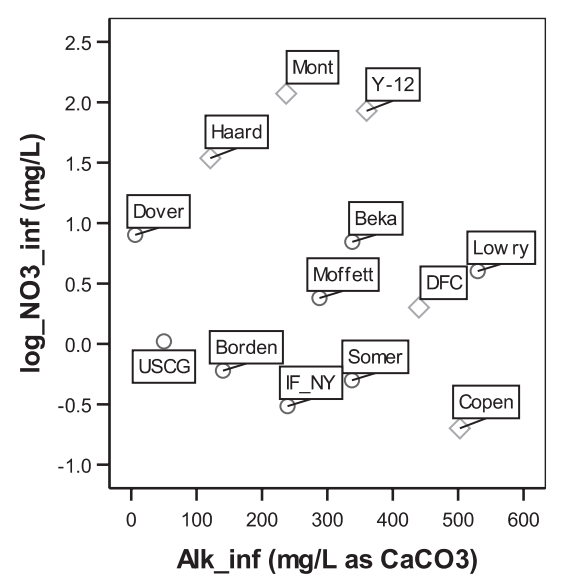

Figure 5. Geochemical parameters with relationship to at-risk and not-at-risk PRBs: (a) Influence chloride vs. internal EH; (b) influent nitrate vs. influent alkalinity. At-risk PRBs are indicated by diamond markers, not-at-risk by circles.

solid, and $E_{H}$, as a master variable, was chosen over the iron(III) solid saturation indices. In addition, it was found that influent alkalinity and chloride were linearly correlated at a $95 \%$ confidence level; however, both parameters were retained because they are not mechanistically related as the parameters in the other categories are.

Univariate logistic regression was carried out for each of the reported and calculated geochemical parameters in

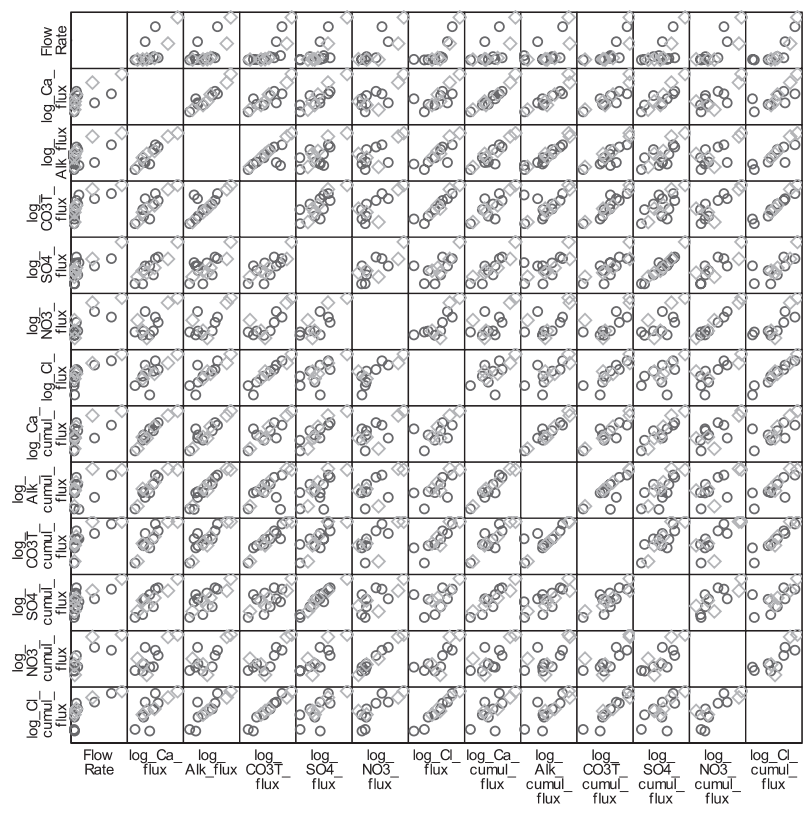

Figure 6. Matrix plot of fluxes, cumulative fluxes, and flow rate showing high degree of collinearity. At-risk PRBs are indicated by diamond markers, not-at-risk by circles.
Tables 4 and 5, with the exception of those parameters eliminated due to high collinearity, reducing the total number of parameters considered from 37 to 21 . The results, presented in Table 7, include $\beta_{1}$ [Eq. (7)] values, the S.E., the Wald value $\left(\beta_{1} /\right.$ S.E. $)$, and the $p$-value, or significance. Variables with a $p$-value $\leq 0.25$ were considered to be significant: influent $\mathrm{pH}$, internal $E_{H}$, influent alkalinity, mass flux of alkalinity, influent chloride, and the use of a pretreatment zone (ptz). Influent nitrate, with a significance of 0.258 , is on the cusp of inclusion. These results agree well with the qualitative graphical analysis. With the exception of influent $\mathrm{pH}$ and ptz, the variables with $p$-values $\leq 0.25$ were also identified visually. A reexamination of the influent $\mathrm{pH}$ data reveals that, while the $\mathrm{pH}$ data are tightly clustered relative to other variables, most at-risk PRBs have influent $\mathrm{pH}$ values $>7$; on the other hand, there are several not-at-risk PRBs with lower influent $\mathrm{pH}$ values, while one, the PRB at Borden, Ontario has an influent $\mathrm{pH}>8$. The probability of a PRB being at risk increases with the use of a pretreatment zone. Though counterintuitive, this appears to be a case of correlation, rather than causation. In cases where performance problems are anticipated, a PTZ is installed, which while undoubtedly useful, does not preclude loss of reactivity or permeability in the reactive zone.

To further corroborate the results of the graphical analysis and the univariate logistic regression, an odds ratio analysis was conducted using the same parameters as for the logistic regression. The results of this analysis are also shown in Table 7, which lists the maximum odds ratio achieved and the cutoff value corresponding to the maximum odds ratio. The two-sided Fisher Exact test was used to evaluate whether the tested variables are inde- 
Table 7. Univariate logistic regression analysis and maximized odds ratio results.

\begin{tabular}{|c|c|c|c|c|c|c|c|c|}
\hline \multirow[b]{2}{*}{ Parameter } & \multirow[b]{2}{*}{ Legend } & \multicolumn{4}{|c|}{ Logistic regression } & \multicolumn{3}{|c|}{ Odds ratio } \\
\hline & & $\beta_{1}$ & $\begin{array}{l}\text { Standard } \\
\text { error }\end{array}$ & $\begin{array}{r}W \\
\text { signi }\end{array}$ & $\begin{array}{l}\text { ald } \\
\text { icance }\end{array}$ & $\begin{array}{c}\text { Max. } \\
\text { odds ratio }\end{array}$ & $\begin{array}{l}\text { Cutoff } \\
\text { value }\end{array}$ & $\begin{array}{c}\text { Fisher exact } \\
\text { test significance }\end{array}$ \\
\hline Run Time (year) & RunTime & -0.1470 & 0.200 & 0.54 & 0.461 & 1.33 & 2.5 & 1.000 \\
\hline Flow Rate (m/day) & FlowRate & 0.1806 & 0.302 & 0.36 & 0.550 & 2 & 1 & 0.604 \\
\hline $\mathrm{pH}$ influent & pH_inf & 0.8910 & 0.700 & 1.62 & 0.203 & 4.67 & 7.2 & 0.302 \\
\hline $\mathrm{pH}$ internal & pH_int & -0.1315 & 0.564 & 0.05 & 0.816 & 3 & 8.9 & 0.500 \\
\hline $\mathrm{E}_{\mathrm{H}}$ internal $(\mathrm{mV})$ & Eh_int & 0.0161 & 0.009 & 3.32 & 0.069 & 60 & -200 & 0.011 \\
\hline TDS influent (mg/L) & TDS_inf & 0.0000 & 0.001 & 0.00 & 0.965 & 5 & 700 & 0.307 \\
\hline DO influent (mg/L) & DO_inf & 0.2015 & 0.334 & 0.36 & 0.547 & 3.6 & 5 & 0.400 \\
\hline $\mathrm{Ca}^{2+}$ influent $(\mathrm{mg} / \mathrm{L})$ & Ca_inf & 0.0035 & 0.006 & 0.39 & 0.534 & 5 & 100 & 0.301 \\
\hline $\mathrm{Ca}^{2+}$ internal $(\mathrm{mg} / \mathrm{L})$ & Ca_int & 0.0106 & 0.012 & 0.84 & 0.359 & 6 & 40 & 0.266 \\
\hline Alk influent $\left(\mathrm{mg} / \mathrm{L}\right.$ as $\left.\mathrm{CaCO}_{3}\right)$ & Alk_inf & 0.0050 & 0.004 & 1.70 & 0.192 & 9 & 350 & 0.118 \\
\hline Alk internal $\left(\mathrm{mg} / \mathrm{L}\right.$ as $\left.\mathrm{CaCO}_{3}\right)$ & Alk_int & 0.0025 & 0.002 & 1.15 & 0.284 & 8 & 200 & 0.235 \\
\hline $\mathrm{CO} 3 \mathrm{~T}$ influent $\left(\mathrm{mg} / \mathrm{L}\right.$ as $\left.\mathrm{CO}_{3}{ }^{2-}\right)$ & CO3T_inf & 0.0007 & 0.002 & 0.09 & 0.759 & 7.5 & 410 & 0.145 \\
\hline $\mathrm{Fe}(\mathrm{T})$ internal $(\mathrm{mg} / \mathrm{L})$ & $\mathrm{Fe} \_$int & -0.0180 & 0.035 & 0.26 & 0.610 & 1.75 & 1.3 & 1.000 \\
\hline $\mathrm{SO}_{4}{ }^{2-}$ influent $(\mathrm{mg} / \mathrm{L})$ & SO4_inf & 0.0003 & 0.001 & 0.04 & 0.840 & 8 & 75 & 0.234 \\
\hline $\mathrm{NO}_{3}{ }^{-}$influent $(\mathrm{mg} / \mathrm{L})$ & NO3_inf & 0.1005 & 0.089 & 1.28 & 0.258 & 24 & 20 & 0.035 \\
\hline $\mathrm{CI}^{-}$influent $(\mathrm{mg} / \mathrm{L})$ & Cl_inf & 0.0246 & 0.018 & 1.93 & 0.165 & 10.67 & 110 & 0.128 \\
\hline Alk Flux (g/m²day) & Alk_flux & 0.0040 & 0.003 & 1.37 & 0.242 & 5 & 25 & 0.307 \\
\hline SI Calcite & SI_calcite & 0.5300 & 0.911 & 0.34 & 0.561 & 9 & 1.15 & 0.192 \\
\hline SI Siderite & SI_siderite & 0.3483 & 0.377 & 0.85 & 0.356 & 8 & -0.2 & 0.208 \\
\hline $\mathrm{SI} \mathrm{Fe}(\mathrm{OH})_{2}$ & SI_feoh2 & 0.9669 & 1.806 & 0.29 & 0.592 & 5.33 & 0.35 & 0.333 \\
\hline PTZ & ptz & 1.6094 & 1.265 & 1.62 & 0.203 & 5 & 1 & 0.307 \\
\hline
\end{tabular}

pendent or associated, with a cutoff significance of $p \leq$ 0.10. Therefore, the geochemical parameters deemed to be most correlated with being at risk via odds ratio maximization were internal $E_{H}$ and influent nitrate. While internal $E_{H}$ was deemed highly significant by logistic regression, influent nitrate was on the borderline. Nitrate (Fig. 4) has outlying points; when fitting these data to the linear regressor equation $g(\mathbf{x})$ [Eq. (7)], it is difficult to estimate an accurate $\beta$ for this parameter, since there are outlying points and each point weighs heavily in the small data set. In contrast, when calculating the odds ratio, there is no weight associated with the extent that a point is an outlier (e.g., with an influent nitrate cutoff of $20 \mathrm{mg} / \mathrm{L}$, the odds ratio treats values of 20.1 and 200 identically). Therefore, outliers do not affect the odds ratio in the same manner as in logistic regression.

Had a less stringent cutoff of, for example, a $p$-value $\leq 0.15$ been chosen, the list of relevant parameters selected via odds ratio maximization would have included influent alkalinity, influent total carbonate, and influent chloride. With the exception of total carbonate, these additional parameters are a subset of those selected via logistic regression. Like influent nitrate, discussed above, the significance of total carbonate is very different when evaluated by logistic regression $($ significance $=0.76$ ) and by odds ratio maximization (Fisher's exact significance $=0.145$ ). An inspection of the data, illustrated in Fig. 7, reveals that, although influent alkalinity and total carbonate are generally well correlated, there is one outlying point-that of the CSM PRB (Australia). This site has an unusually low $\mathrm{pH}$, and hence, its low alkalinity does not correspond to low total carbonate. As in the case of nitrate, this outlier affects the fit such that the logistic regression using total carbonate predicts no at-risk PRBs for any of the total carbonate values in the data set. In contrast, the alkalinity values lack outliers, and hence, the estimated $\beta$ value is more meaningful.

Both of the statistical approaches utilized here corroborated the qualitative graphical observations. TDS and DO are not major parameters in determining at-risk PRBs. However, influent $\mathrm{pH}$, internal $E_{H}$, influent alkalinity, influent chloride, influent nitrate, mass flux of alkalinity, and use of a pretreatment zone are significant for describing at-risk PRBs. Despite the problems inherent with measuring $E_{H}$ in the field (Sposito, 1989), both statistical approaches showed that this parameter has strong predictive power. While both approaches agreed on the significance of some parameters, influent nitrate was found to be more significant in the odds ratio analysis than in the logistic regression. 


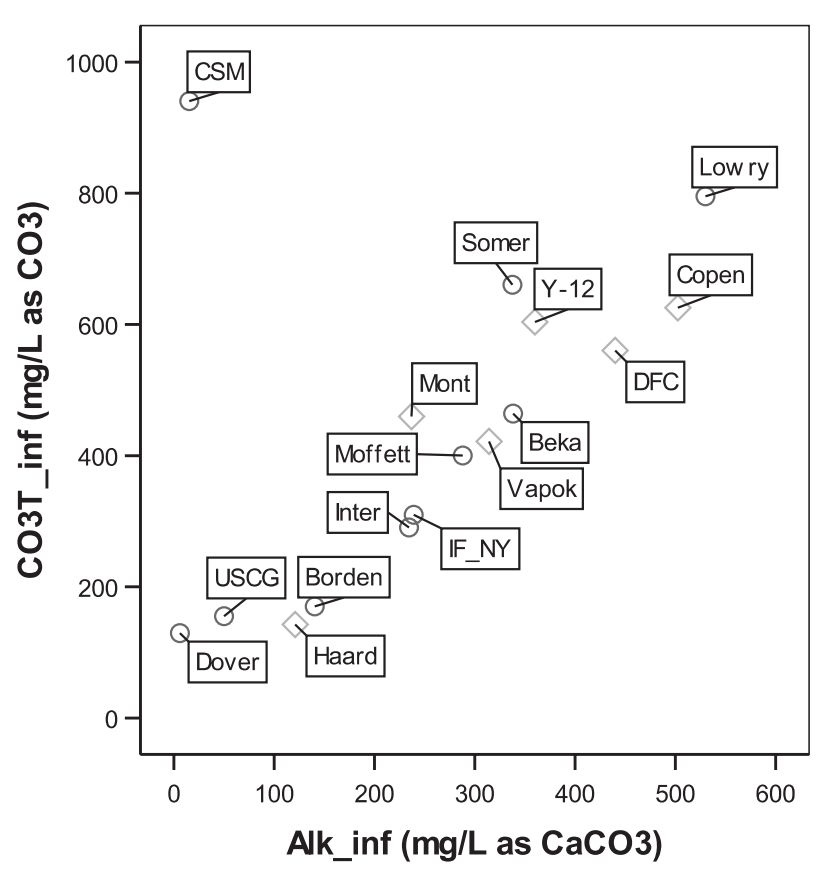

Figure 7. Differences between influent alkalinity and influent total carbonate; the CSM (Australia) PRB has unusually low influent $\mathrm{pH}$. At-risk PRBs are indicated by diamond markers, not-at-risk by circles.

To better assess the relative significance and potential interaction of terms, multivariate logistic regression was performed with the combination of the parameters selected using the univariate logistic regression $(p$-value $\leq 0.25)$ and the maximization of the odds ratio ( $p$-value $\leq 0.10)$ : $\mathrm{pH} \_$inf, Eh_int, Alk_inf, NO3_inf, Cl_inf, Alk_flux, and ptz. Yet for this limited data set, internal $E_{H}$ and influent chloride are "perfect predictors," separating the data set completely into at-risk and not-at-risk groupings (Fig. 5a). Furthermore, the parameter subset influent alkalinity (or influent chloride, which is linearly correlated at the $95 \%$ confidence level), alkalinity mass flux, and influent nitrate perfectly predicted the data. Including perfect predictors into multivariate regression results in unstable parameter estimates (Faraway, 2006). Because of the limitations of the size of the data set, the best multivariate logistic regression that could be achieved included no interaction terms and only the parameters pH_inf, Alk_inf, and Alk_flux. Even so, this model predicted at-risk PRBs with an $87.5 \%$ success rate, with Alk_flux significant at a $90 \%$ confidence level and the other two at an $80 \%$ confidence level.

\section{CONCLUSIONS}

PRBs, despite the lack of a thorough understanding of the processes therein, have worked well in most in situ installations, as evidenced by the few PRBs reported to have failed. Indeed, nearly all in situ PRBs that use ZVI (i.e., rather than experimental media) and treat contaminants at field concentrations (i.e., not at the artificially high concentrations found in the laboratory) have met their design goals (Liang et al., 2000). Furthermore, most PRBs continue to treat contaminants well despite the occurrence of potential problems such as porosity reduction. However, the current lack of understanding makes this apparent robustness seem fortuitous rather than designed.

The literature suggests that the major issue in PRB performance resulting in failure is design flaws (such as improper hydraulic characterization of a site), rather than depletion of media reactivity or media plugging. Predictions of severe plugging, usually based on laboratory work performed using conditions that are not representative of the field (elevated DO, abnormal concentrations and combinations of inorganic groundwater constituents, and high flow rates), are generally not borne out by field experience at in situ PRBs. Ex situ PRBs, on the other hand, experience conditions closer to the laboratory and suffer from high failure rates due to clogging, both from gas and precipitate production.

The quantitative analyses performed here suggest that high influent $\mathrm{pH}$, internal $E_{H}$, high influent concentrations of nitrate, chloride, and alkalinity, are problematic for PRBs. Other parameters such as TDS, DO, and the SI of carbonate solids that have been suggested in the literature as controlling PRB longevity did not appear to have much predictive ability for classifying a PRB as at risk. Ideally, the parameters selected by univariate regression should be utilized in multivariate modeling to gain a better understanding of the relative significance of the parameters. However, the sparseness of the dataset made certain combinations of variables, like $E_{H}$ and $\mathrm{Cl}^{-}$, perfect predictors, precluding their use in a multivariate analysis. Consequently, differentiating between reactivity and hydraulic changes as the dominant factor controlling PRB longevity with any certainty is not possible with the currently available data. Yet, the preponderance of variables selected as significant, $E_{H}$, alkalinity, and $\mathrm{NO}_{3}{ }^{-}$influence PRB performance through their impact on ZVI reactivity. Thus, it appears that the inhibition of ZVI corrosion, rather than the loss of permeability, may determine PRB longevity.

As many PRBs begin their second decade of operation, they may be nearing the end of their estimated life spans (Table 2). Thus, it becomes critical that field PRBs are monitored more closely to determine the factors that control the time to failure. If it appears that precipitation at the upgradient face is dominant, lifetimes may be extended by the installation of a PTZ containing reactive 
media, or by the periodic replacement of the first 20-30 $\mathrm{cm}$ of the PRB where the precipitates are concentrated. If media reactivity is the issue, then efforts should be directed toward developing methods for rejuvenating media in situ (Gavaskar, 1999; Gillham, 1999; Ott, 2000). Field experience suggests that PRBs are a more robust technology than one might anticipate based on laboratory column experiments. Thus, more detailed and comprehensive field monitoring is crucial to determining modes of failure and, in turn, PRBs' cost effectiveness as a longterm treatment technology.

\section{ACKNOWLEDGMENTS}

The authors gratefully acknowledge the funding for this research from the Strategic Environmental Research and Development Program (SERDP) under grant Department of Defense, Department of Army, Contract Number W912HQ-04-C-0035. This paper has not been subject to agency review; it therefore does not necessarily reflect the sponsor's view, and no official endorsement should be inferred.

\section{REFERENCES}

ABDELMOULA, M., REFAIT, P., DRISSI, S.H., MIHE, J.P., and GENIN, J.R. (1996). Conversion electron mossbauer spectroscopy and X-ray diffraction studies of the formation of carbonate-containing green rust one by corrosion metallic iron in $\mathrm{NaHCO}_{3}$ and $\left(\mathrm{NaHCO}_{3}+\mathrm{NaC1}\right)$ solutions. Corros. Sci. 38, 623.

AGRAWAL, A., and TRATNYEK, P.G. (1996). Reduction of nitro aromatic compounds by zero-valent iron metal. Environ. Sci. Technol. 30, 153.

AL-AGHA, M.R., BURLEY, S.D., CURTIS, C.D., and ESSON, J. (1995). Complex cementation textures and authigenic mineral assemblages in recent concretions from the Lincolnshire wash (East coast, UK) driven by $\mathrm{Fe}(0)$ to $\mathrm{Fe}$ (II) oxidation. J. Geol. Soc. Lond. 152, 157.

BLOWES, D.W., GILLHAM, R.W., PTACEK, C.J., PULS, R.W., BENNETT, T.A., O'HANNESIN, S.F., HANTONFONG, C., and BAIN, J. (1999). In Situ Permeable Reactive Barrier for the Treatment of Hexavalent Chromium and Trichloroethylene in Ground Water: Volume 1. Design and Installation. Report \# EPA/600/R99/095A. Washington, DC: United States Environmental Protection Agency.

BLOWES, D.W., PULS, R.W., GILLHAM, R.W., PTACEK, C.J., BENNETT, T.A., BAIN, J., HANTON-FONG, C., and PAUL, C.J. (1999). In Situ Permeable Reactive Barrier for the Treatment of Hexavalent Chromium and Trichloroethylene in Ground Water. Volume 2. Performance Monitoring.
Report \# EPA/600/R99/095B. Washington, DC: United States Environmental Protection Agency.

BLOWES, D.W., PTACEK, C.J., BENNER, S.G., MCRAE, C.W.T., BENNETT, T.A., and PULS, R.W. (2000). Treatment of inorganic contaminants using permeable reactive barriers. J. Contam. Hydrol. 45, 123.

D'ANDREA, P., LAI, K.C.K., KJELDSEN, P., and LO, I.M.C. (2005). Effect of groundwater inorganics on the reductive dechlorination of TCE by zero-valent iron. Water Air Soil Pollut. 162, 401.

DENG, B., HU, S.,WHITWORTH, T.M., and LEE, R. (2003). Trichloroethylene reduction on zerovalent iron: Probing reactive versus nonreactive sites. In S. Henry, Ed., Innovative Strategies for the Remediation of Chlorinated Solvents and DNAPLS in the Subsurfaces. Washington, DC: American Chemical Society, p. 181.

DEVLIN, J.F., and ALLIN, K.O. (2005). Major anion effects on the kinetics and reactivity of granular iron in glass-encased magnet batch reactor experiments. Environ. Sci. Technol. 39, 1868.

DEVLIN, J.F., KLAUSEN, J., and SCHWARZENBACH, R.P. (1998). Kinetics of nitroaromatic reduction on granular iron in recirculating batch experiments. Environ. Sci. Technol. 32, 1941.

DURAN, J.M., VOGAN, J.L., and STENING, J.R. (2000). Reactive barrier performance in a complex contaminant and geochemical environment. In G.B. Wickramanayake, A.R. Gavaskar, and A.S.C. Chen, Eds., Chemical Oxidation and Reactive Barriers: Remediation of Chlorinated and Recalcitrant Compounds. Columbus, $\mathrm{OH}$ : Battelle Press, p. 401.

DWYER, B.P. (2000). Evaluation of a Permeable Reactive Barrier Technology for Use at Rocky Flats Environmental Technology Site (RFETS). Report \# SAND-2000-0075. Albuquerque, NM: Sandia National Laboratories.

EPA. (1999). Field Applications of in Situ Remediation Technologies: Permeable Reactive Barriers. Report \# 542-R-99002. Washington, DC: United States Environmental Protection Agency, Office of Solid Waste and Emergency Response.

EPA. (2002). Field Applications of in Situ Remediation Technologies: Permeable Reactive Barriers. Washington, DC: United States Environmental Protection Agency, Office of Solid Waste and Emergency Response.

ESTCP. (2003). Evaluating the Longevity and Hydraulic Performance of Permeable Reactive Barriers at Department of Defense Sites. Report \# CU-9907. Washington, DC: U.S. Department of Defense, Environmental Security Technology Certification Program.

FARAWAY, J.J. (2006). Extending the Linear Model with R: Generalized Linear, Mixed Effects and Nonparametric Regression Models. Boca Raton, FL: Chapman \& Hall/CRC. 
FARRELL, J., KASON, M., MELITAS, N., and LI, T. (2000). Investigation of the long-term performance of zero-valent iron for reductive dechlorination of trichloroethylene. Environ. Sci. Technol. 34, 514.

FRTR. (2002). Evaluation of Permeable Reactive Barrier Performance: Revised Report. Federal Remediation Technologies Roundtable; Tri-Agency Permeable Reactive Barrier Initiative.

FURUKAWA, Y., KIM, J.W., WATKINS, J., and WILKIN, R.T. (2002). Formation of ferrihydrite and associated iron corrosion products in permeable reactive barriers of zero-valent iron. Environ. Sci. Technol. 36, 5469.

GAVASKAR, A.R. (1999). Design and construction techniques for permeable reactive barriers. J. Hazard. Mater. 68, 41.

GAVASKAR, A.R., GUPTA, N., SASS, B.M., FOX, T.C., JANOSY, R., CANTRELL, K.J., and OLFENBUTTEL, R. (1997). Design Guidance for Application of Permeable Barriers to Remediate Dissolved Chlorinated Solvents. Report \# DG 1110-345-117. Tyndall AFB, FL: United States Air Force.

GAVASKAR, A., GUPTA, N., SASS, B., YOON, W., JANOSY, R., DRESCHER, E., and HICKS, J. (2000). Design, Construction and Monitoring of the Permeable Reactive Barrier in Area 5 at Dover Air Force Base. Report \# AFRL-ML-TY-2000-4546. Columbus, OH: Battelle.

GAVASKAR, A., YOON, W.S., SMINCHACK, J., SASS, B., GUPTA, N., HICKS, J., and LAL, V. (2005). Long Term Performance Assessment of a Permeable Reactive Barrier at Former Naval Air Station Moffett Field. Report \# CR 05006-ENV. Port Hueneme, CA: Naval Facilities Engineering Command.

GILLHAM, R.W. (1999). In situ remediation of VOC-contaminated groundwater using zero-valent iron: Long-term performance. In Proceedings of the 1999 Contaminated Site Remediation Conference Challenges Posed by Urban \& Industrial Contaminants. Centre for Groundwater Studies, Adelaide, Australia, p. 605.

GILLHAM, R.W., and O'HANNESIN, S.F. (1992). Metal-catalyzed abiotic degradation of halogenated organic compounds. In IAH Conference: Modern Trends in Hydrogeology, p. 94.

GILLHAM, R.W., and O'HANNESIN, S.F. (1994). Enhanced degradation of halogenated aliphatics by zero-valent iron. Groundwater 32, 958.

GILLHAM, R.W., O'HANNESIN, S.F., and ORTH, W.S. (1993). Metal enhanced abiotic degradation of halogenated aliphatics: Laboratory tests and field trials. In W.R. Bunner, Ed., 6th Annual Environmental Management and Technology Conference, Advanstar Expositions, Glen Ellyn, IL, p. 440.

GU, B. (2005a). Iron reactive barrier at the Oak Ridge Y-12 site: Mineralogical characteristics. http://www.esd.ornl.gov/ $\sim$ b26/minerals.htm. Accessed 4/1/2005.
GU, B. (2005b). Iron Reactive Barrier at the Oak Ridge Y-12 Site: Project Summary. http://www.esd.ornl.gov/ b26/barrier.htm. Accessed 4/1/2005.

GU, B., PHELPS, T.J., LIANG, L.Y., DICKEY, M.J., ROH, Y., KINSALL, B.L., PALUMBO, A.V., and JACOBS, G.K. (1999). Biogeochemical dynamics in zero-valent iron columns: Implications for permeable reactive barriers. Environ. Sci. Technol. 33, 2170.

GU, B.,WATSON, D.B.,PHILLIPS, D.H., and LIANG, L.Y. (2002). Biogeochemical, mineralogical, hydrological characteristics of an iron reactive barrier used for treatment of uranium and nitrate. In D.L. Naftz, S.J. Morrison, J.A. Davis, and C.C. Fuller, Eds., Handbook of Groundwater Remediation Using Permeable Reactive Barriers: Applications to Radionuclides, Trace Metals, and Nutrients. San Diego, CA: Academic Press, p. 305.

HOSMER, D.W., and LEMESHOW, S. (1989). Applied Logistic Regression. New York: Wiley.

ITRC. (2005). Permeable Reactive Barriers: Lessons Learned/ New Directions. Report \# PRB-4. Washington, DC: Interstate Technology \& Regulatory Council, Permeable Reactive Barriers Team.

JAIN, A., RAVEN, K.P., and LOEPPERT, R.H. (1999). Arsenite and arsenate adsorption on ferrihydrite: Surface charge reduction and net $\mathrm{OH}-$ release stoichiometry. Environ. Sci. Technol. 33, 1179.

JAMBOR, J.L., RAUDSEPP, M., and MOUNTJOY, K. (2005). Mineralogy of permeable reactive barriers for the attenuation of subsurface contaminants. Can. Mineral. 43, 2117.

JOHNSON, R.L., TRATNYEK, P.G., MIEHR, R., THOMS, R.B., and BANDSTRA, J.Z. (2005). Reduction of hydraulic conductivity and reactivity in zero-valent iron columns by oxygen and TNT. Ground Water Monit. Remediat. 25, 129.

JOHNSON, T.L., FISH, W., GORBY, Y.A., and TRATNYEK, P.G. (1998). Degradation of carbon tetrachloride by iron metal: Complexation effects on the oxide surface. J. Contam. Hydrol. 29, 379.

KAMOLPORNWIJIT, W., LIANG, L.Y., WEST, O.R., MOLINE, G.R., and SULLIVAN, A.B. (2003). Preferential flow path development and its influence on long-term PRB performance: Column study. J. Contam. Hydrol. 66, 161.

KIELEMOES, J., DE BOEVER, P., and VERSTRAETE, W. (2000). Influence of denitrification on the corrosion of iron and stainless steel powder. Environ. Sci. Technol. 34, 663.

KIILERICH, O., LARSEN, J.W., NIELSEN, C., and DEIGAARD, L.D. (2000). Field results from the use of a permeable reactive wall. In G.B. Wickramanayake, A.R. Gavaskar, and A.S.C. Chen, Eds. Chemical Oxidation and Reactive Barriers: Remediation of Chlorinated and Recalcitrant Compounds. Columbus, OH: Battelle Press, p. 377. 
KJELDSEN, P., and FULGSANG, I.A. (2000). Demonstration program on reactive barrier technologies using zero-valent iron. In ConSoil 2000. London: Thomas Telford, p. 943.

KJELDSEN, P., and LOCHT, T. (2000). Removal of TCE and chromate in reactive barriers using zero-valent iron: Laboratory experiments. In ConSoil 2000. London: Thomas Telford, p. 1146.

KLAUSEN, J., RANKE, J., and SCHWARZENBACH, R.P. (2001). Influence of solution composition and column aging on the reduction of nitroaromatic compounds by zero-valent iron. Chemosphere 44, 511.

KLAUSEN, J., VIKESLAND, P.J., KOHN, T., BURRIS, D.R., BALL, W.P., and ROBERTS, A.L. (2003). Longevity of granular iron in groundwater treatment processes: Solution composition effects on reduction of organohalides and nitroaromatic compounds. Environ. Sci. Technol. 37, 1208.

KLEIN, R., and SCHAD, H. (2000). Results from a full-scale funnel-and-gate system at the BEKA site in Tubingen (Germany) using zero-valent iron. In ConSoil 2000. London: Thomas Telford, p. 917.

KÖBER, R., SCHLICKER, O., EBERT, M., and DAHMKE, A. (2002). Degradation of chlorinated ethylenes by $\mathrm{Fe}^{0}$ : Inhibition processes and mineral precipitation. Environ. Geol. 41, 644 .

KÖBER, R., GIAROLLI, F., EBERT, M., and DAHMKE, A. (2005). Long-term performance of $\mathrm{Fe}^{0}$-PRBs to treat arsenic and 1,2-DCE( $($ is $)$ under different geochemical conditions. In G. Boshoff, and B.D. Bone, Eds., First International Symposium on Permeable Reactive Barriers; IAHS Publication 298. Oxfordshire, UK: IAHS Press, p. 3.

KORTE, N.E. (2001). Zero-Valent Iron Permeable Reactive Barriers: A Review of Performance. Report \# ORNL/TM2000/345. Oak Ridge, TN: Oak Ridge National Laboratory.

KORTE, N.E., LIANG, L.Y., GU, B., MUCK, M.T., ZUTMAN, J.L., SCHLOSSER, R.M., SIEGRIST, R.L., HOUK, T.C., and FERNANDO, Q. (1997a). In Situ Treatment of Mixed Contaminants in Groundwater: Application of ZeroValence Iron and Palladized Iron for Treatment of Groundwater Contaminated with Trichloroethene and Technetium99. Report \# ORNL/TM-13530. Oak Ridge, TN: Oak Ridge National Laboratory.

KORTE, N.E., WEST, O.R., LIANG, L.Y., PELFREY, M.J., and HOUK, T.C. (1997b). A field-scale test facility for permeable reactive barriers at the portsmouth gaseous diffusion plant. Fed. Fac. Environ. J. 8, 105.

LACKOVIC, J.A., NIKOLAIDIS, N.P., and DOBBS, G.M. (2000). Inorganic arsenic removal by zero-valent iron. Environ. Eng. Sci. 17, 29.

LAI, K.C.K., KJELDSEN, P., and LO, I.M.C. (2005). Evaluation of the hydraulic performance of a full-scale permeable reactive barrier by a tracer study. In G.A. Boshoff, and B.D. Bone, Eds., First International Symposium on Permeable Re- active Barriers, Belfast, United Kingdom, March 2004. Oxfordshire, UK: IAHS-AISH Press, p. 144.

LAI, K.C.K., LO, I.M.C., BIRKELUND, V., and KJELDSEN, P. (2006). Field monitoring of a permeable reactive barrier for removal of chlorinated organics. J. Environ. Eng. 132, 199.

LI, L., and BENSON, C.H. (2005). Impact of fouling on the long-term hydraulic behaviour of permeable reactive barriers. In G. Boshoff, and B.D. Bone, Eds., First International Symposium on Permeable Reactive Barriers. IAHS Publication 298, Oxfordshire, UK: IAHS Press, p. 23.

LIANG, L.Y., KORTE, N.E., GU, B., PULS, R., and REETER, C. (2000). Geochemical and microbial reactions affecting the long-term performance of in situ "iron barriers." $\underline{A d v}$. Environ. Res. 4, 273.

LIANG, L.Y., KORTE, N.E., MOLINE, G.R., and WEST, O.R. (2001). Long-Term Monitoring of Permeable Reactive Barriers: Progress Report. Report \#ORNL/TM-2001/1. Oak Ridge, TN: Oak Ridge National Laboratory.

LIANG, L.Y., WEST, O.R., KORTE, N.E., GOODLAXSON, J.D., PICKERING, D.A., ZUTMAN, J.L., ANDERSON, F.J., WELCH, C.A., PELFREY, M.J., and DICKEY, M.J. (1997). The X-625 Groundwater Treatment Facility: A FieldScale Test of Trichloroethylene Dechlorination using Iron Filings for the X-120/X-749 Groundwater Plume. Report \# ORNL/TM-13410. Oak Ridge, TN: Oak Ridge National Laboratory.

LIANG, L.Y., SULLIVAN, A.B., WEST, O.R., MOLINE, G.R., and KAMOLPORNWIJIT, W. (2003). Predicting the precipitation of mineral phases in permeable reactive barriers. Environ. Eng. Sci. 20, 635.

LIEN, H., and WILKIN, R.T. (2005). High-level arsenite removal from groundwater by zero-valent iron. Chemosphere 59, 377 .

MACKENZIE, P.D., HORNEY, D.P., and SIVAVEC, T.M. (1999). Mineral precipitation and porosity losses in granular iron columns. J. Hazard. Mater. 68, 1.

MAYER, K.U. (1999). A numerical model for multicomponent reactive transport in variably saturated porous media. Ph.D. thesis, University of Waterloo, Waterloo, Ontario, Canada.

MCCORMICK, N.J. (1981). Reliability and Risk Analysis: Methods and Nuclear Power Applications. New York: Academic Press.

MCMAHON, P.B., DENNEHY, K.F., and SANDSTROM, M.W. (1999). Hydraulic and geochemical performance of a permeable reactive barrier containing zero-valent iron, denver federal center. Groundwater 37, 396.

MELITAS, N., WANG, J.P., CONKLIN, M., O'DAY, P., and FARRELL, J. (2002). Understanding soluble arsenate removal kinetics by zerovalent iron media. Environ. Sci. Technol. 36, 2074. 
MORRISON, S.J., METZLER, D.R., and CARPENTER, C.E. (2001). Uranium precipitation in a permeable reactive barrier by progressive irreversible dissolution of zerovalent iron. Environ. Sci. Technol. 35, 385.

MORRISON, S.J., CARPENTER, C.E., METZLER, D.R., BARTLETT, TIMOTHY R., and MORRIS, S.A. (2002a). Design and performance of a permeable reactive barrier for containment of uranium, arsenic, selenium, vanadium, molybdenum, and nitrate at Monticello, Utah. In D.L. Naftz, S.J. Morrison, J.A. Davis, and C.C. Fuller, Eds., Handbook of Groundwater Remediation Using Permeable Reactive Barriers: Applications to Radionuclides, Trace Metals, and Nutrients. San Diego, CA: Academic Press, p. 371.

MORRISON, S.J., METZLER, D.R., and DWYER, B.P. (2002b). Collection drain and permeable reactive barrier for treating uranium and metals from mill tailings near Durango, Colorado. In D.L. Naftz, S.J. Morrison, J.A. Davis, and C.C. Fuller, Eds., Handbook of Groundwater Remediation using Permeable Reactive Barriers: Applications to Radionuclides, Trace Metals, and Nutrients. San Diego, CA: Academic Press, p. 435.

MORRISON, S.J., METZLER, D.R., and DWYER, B.P. (2002c). Removal of As, Mn, Mo, Se, U, V and Zn from groundwater by zero-valent iron in a passive treatment cell: Reaction progress modeling. J. Contam. Hydrol. 56, 99.

MORRISON, S.J., NAFTZ, D.L., DAVIS, J.A., and FULLER, C.C. (2002d). Introduction to groundwater remediation of metals, radionuclides, and nutrients with permeable reactive barriers; In D.L. Naftz, S.J. Morrison, J.A. Davis, and C.C. Fuller, Eds., Handbook of Groundwater Remediation Using Permeable Reactive Barriers: Applications to Radionuclides, Trace Metals, and Nutrients. San Diego, CA: Academic Press, p. 1.

MUSHOVIC, P., BARTLETT, T., and MORRISON, S.J. (2006). Hydraulic conductivity loss at the Monticello PRB leads to trial use of ex-situ treatment cell. Tech. News Trends 1.

MYERS, R.H. (1990). Classical and Modern Regression with Applications. Boston: PWS-Kent.

NATIONAL RESEARCH COUNCIL. (1994). Alternatives for Ground Water Cleanup. Washington, DC: National Academy Press.

NICHOLSON, R.V., CHERRY, J.A., and REARDON, E.J. (1983). Migration of contaminants in ground water at a landfill: A case study. 6. Hydrogeochemistry. J. Hydrol. (Amst.) 63, 131.

O'HANNESIN, S.F. (1993). Field Demonstration of a Permeable Reaction Wall for the in Situ Abiotic Degradation of Halogenated Aliphatic Organic Compounds. Waterloo, Ontario, Canada: University of Waterloo.

O'HANNESIN, S.F., and GILLHAM, R.W. (1998). Long-term performance of an in situ "iron wall" for remediation of VOCs. Groundwater 36, 164.
OTT, N. (2000). Permeable Reactive Barriers for Inorganics. Washington, DC: United States Environmental Protection Agency.

PHILLIPS, D.H., GU, B., WATSON, D.B., ROH, Y., LIANG, L.Y., and LEE, S.Y. (2000). Performance evaluation of a zerovalent iron reactive barrier: Mineralogical characteristics. Environ. Sci. Technol. 34, 4169.

PHILlIPS, D.H., WATSON, D.B., ROH, Y., and GU, B. (2003). Mineralogical characteristics and transformations during long-term operation of a zerovalent iron reactive barrier. J. Environ. Qual. 32, 2033.

POWELL, R.M. and POWELL, P.D. (2002). Economic Analysis of the Implementation of Permeable Reactive Barriers for Remediation of Contaminated Ground Water. Report \# EPA/600/R-02/034. Washington, DC: United States Environmental Protection Agency.

POWELL, R.M., PULS, R.W., BLOWES, D.W., VOGAN, J.L., GILlHAM, R.W., POWELL, P.D., SCHULTZ, D., SIVAVEC, T.M., and LANDIS, R. (1998). Permeable Reactive Barriers Technologies for Contaminant Remediation. Report \# EPA/600/R-98/125. Washington, DC: United States Environmental Protection Agency.

PULS, R.W., BLOWES, D.W., and GILLHAM, R.W. (1999). Long-term performance monitoring for a permeable reactive barrier at the US Coast Guard Support Center, Elizabeth City, North Carolina. J. Hazard. Mater. 68, 109.

PURDY, C., GERDES, K., ALJAYOUSHI, J., KABACK, D., and IVORY, T. (2002). Examples of Department of Energy successes for remediation of contaminated groundwater: Permeable reactive barrier and dynamic underground stripping ASTD projects. In 28th Annual Waste Management Conference, WM Symposia, Tucson, AZ.

REYNOLDS, G.W., HOFF, J.T., and GILLHAM, R.W. (1990). Sampling bias caused by materials used to monitor halocarbons in groundwater. Environ. Sci. Technol. 24, 135.

RHODES, F.H., and CARTY, J.T. (1925). The corrosion of certain metals by carbon tetrachloride. Indust. Eng. Chem. 17, 909.

RITTER, K., ODZIEMKOWSKI, M.S., and GILLHAM, R.W. (2002). An in situ study of the role of surface films on granular iron in the permeable iron wall technology. J. Contam. Hydrol. 55, 87.

ROBERTS, L.R., BALL, W.P., SEARSON, P., FAIRBROTHER, H., VIKESLAND, P.J., KLAUSEN, J., ZIMMERMANN, H.J., and BURRIS, D. (2002). Final Report for the SERDP Project CU-1125: Influence of Groundwater Constituents on Longevity of Iron-Based Permeable Barriers. Report \# CU-1125. Baltimore, MD: John Hopkins University.

RTDF. (2001). Permeable reactive barrier installation profiles. http://www.rtdf.org/public/permbarr/prbsumms/default.cfm. Accessed 1 March 2005.

ENVIRON ENG SCI, VOL. 24, NO. 4, 2007 
SARR, D. (2001). Zero-valent-iron permeable reactive barriers-How long will they last? Remediation 11, 1.

SASS, B.M., GAVASKAR, A.R., GUPTA, N., YOON, S.W., HICKS, J.E., O'DWYER, D., and REETER, C. (1998). Evaluating the Moffett Field permeable barrier using groundwater monitoring and geochemical modeling. In G.B. Wickramanayake, and R.E. Hinchee, Eds., Designing and Applying Treatment Technologies: Remediation of Chlorinated and Recalcitrant Compounds: The First International Conference on Remediation of Chlorinated and Recalcitrant Compounds. Columbus, OH: Battelle Press, p. 169.

SCHERER, M.M., RICHTER, S., VALENTINE, R.L., and ALVAREZ, P.J.J. (2000). Chemistry and microbiology of permeable reactive barriers for in situ groundwater clean up. Crit. Rev. Environ. Sci. Technol. 30, 363.

SCHLICKER, O., EBERT, M., FRUTH, M., WEIDNER, M., WÜST, W., and DAHMKE, A. (2000). Degradation of TCE with iron: The role of competing chromate and nitrate reduction. Groundwater 38, 403.

SENZAKI, T. (1991). Removal of chlorinated organic compounds from wastewater by reduction process: II. Treatment of trichloroethylene with iron powder II. Kogyo Yosui 391, 29.

SENZAKI, T., and KUMAGAI, Y. (1988). Removal of chlorinated organic compounds from wastewater by reduction process: I. Treatment of 1,1,2,2-tetrachloroethane with iron powder. Kogyo Yosui 357, 2.

SENZAKI, T., and KUMAGAI, Y. (1989). Removal of chlorinated organic compounds from wastewater by reduction process: II. Treatment of trichloroethylene with iron powder. Kogyo Yosui 369, 19.

SHOEMAKER, S.H.,GREINER, J.F., and GILLHAM, R.W. (1995). Permeable reactive barriers. In R.R. Rumer and J.K. Mitchell, Eds., Assessment of Barrier Containment Technologies. Springfield, VA: National Technical Information Service, p. 301.

SIMON, F., MEGGYES, T., TUNNERRNEIER, T., CZURDA, K., and ROEHL, K.E. (2001). Long-term behaviour of permeable reactive barriers used for the remediation of contaminated groundwater. In 8th International Conference on Radioactive Waste Management and Environmental Remediation, Sep 30-Oct 4 2001. Bruges, Belgium: American Society of Mechanical Engineers, p. 637.

SIVAVEC, T., KRUG, T., BERRY-SPARK, K., and FOCHT, R. (2003). Performance monitoring of a permeable reactive barrier at the Somersworth, New Hampshire landfill Superfund site. Chlorinated Solvent DNAPL Remediat. 837, 259.

SOREL, D.,WARNER, S.D., LONGINO, B.L., HONNIBALL, J.H., and HAMILTON, L.A. (2003). Performance monitoring and dissolved hydrogen measurements at a permeable zero valent iron reactive barrier. In S.M. Henry and S.D. Warner, Eds., Chlorinated Solvent and DNAPL Remediation: Innovative Strategies for Subsurface Cleanup. Washington,
DC: American Chemical Society: Distributed by Oxford University Press, p. 278.

SPOSITO, G. (1989). The Chemistry of Soils. New York: Oxford University Press.

STUMM, W., and MORGAN, J.J. (1996). Aquatic Chemistry: Chemical Equilibria and Rates in Natural Waters. New York: Wiley.

SU, C., and PULS, R.W. (2004). Significance of iron(II,III) hydroxycarbonate green rust in arsenic remediation using zerovalent iron in laboratory column tests. Environ. Sci. Technol. 38, 5224.

SU, C., and PULS, R.W. (2003). In situ remediation of arsenic in simulated groundwater using zerovalent iron: Laboratory column tests on combined effects of phosphate and silicate. Environ. Sci. Technol. 37, 2582.

SU, C., and PULS, R.W. (2001). Arsenate and arsenite removal by zerovalent iron: Effects of phosphate, silicate, carbonate, borate, sulfate, chromate, molybdate, and nitrate, relative to chloride. Environ. Sci. Technol. 35, 4562.

SWEENY, K.H. (1981a). The reductive treatment of industrial wastewaters. I. Process description. AIChE Sypm. Series 77, 67.

SWEENY, K.H. (1981b). The reductive treatment of industrial wastewaters. II. Process applications. AIChE Symp. Series 77, 72 .

SWEENY, K.H., and FISCHER, J.R. (1972). Reductive degradation of halogenated pesticides. February 81972. U.S. Patent \# 3640821.

SWEENY, K.H., and FISCHER, J.R. (1973). Decomposition of halogenated pesticides. 1973. U.S. Patent \# 3640821.

TAYLOR, S.W., MILLY, P.C.D., and JAFFE, P.R. (1990). Biofilm growth and the related changes in the physical properties of a porous medium. 2, Permeability. Water Resour. Res. 26, 2161.

TRATNYEK, P. (1996). Putting corrosion to use: Remediating contaminated groundwater with zero-valent metals. Chem. Industry (Lond.) 499.

TRATNYEK, P.G. (2002). Keeping up with all that literature: The IronRefs database turns 500. Groundwater Monit. Remediat. 22, 92 .

UHLIG, H.H., and REVIE, R.W. (1985). Corrosion and Corrosion Control: An Introduction to Corrosion Science and Engineering. New York: Wiley.

U.S. DOE-SUBSURFACE CONTAMINANTS FOCUS AREA. (2000). Permeable Reactive Treatment (PeRT) Wall for Rads and Metals. Report \# OST/TMS ID 2155. United States Department of Energy.

VANDEVIVERE, P., and BAVEYE, P. (1992). Relationship between transport of bacteria and their clogging efficiency in sand columns. Appl. Environ. Microbiol. 58, 2523. 
VIKESLAND, P.J., KLAUSEN, J., ZIMMERMANN, H.J., ROBERTS, A.L., and BALL, W.P. (2003). Longevity of granular iron in groundwater treatment processes: Changes in solute transport properties over time. J. Contam. Hydrol. $64,3$.

VOGAN, J.L., BUTLER, B.J., ODZIEMKOWSKI, M.S., FRIDAY, G., and GILLHAM, R.W. (1998). Inorganic and biological evaluation of cores from permeable iron reactive barriers. In G.B. Wickramanayake, and R.E. Hinchee, Eds, Designing and Applying Treatment Technologies: Remediation of Chlorinated and Recalcitrant Compounds: The First International Conference on Remediation of Chlorinated and Recalcitrant Compounds. Columbus, OH: Battelle Press, p. 163.

VOGAN, J.L., FOCHT, R.M., CLARK, D.K., and GRAHAM, S.L. (1999). Performance evaluation of a permeable reactive barrier for remediation of dissolved chlorinated solvents in groundwater. J. Hazard. Mater. 68, 97.

WARNER, S.D., and SOREL, D. (2003). Ten years of permeable reactive barriers: Lessons learned and future expectations. In S.M. Henry and S.D. Warner, Eds., Chlorinated Solvent and DNAPL Remediation: Innovative Strategies for Subsurface Cleanup. Washington, DC: American Chemical Society, p. 36.

WARNER, S.D., YAMANE, C.L., BICE, N.T., SZERDY, F.S., VOGAN, J.L., MAJOR, D.W., and HANKINS, D.A. (1998). Technical update: The first commercial subsurface permeable reactive treatment zone composed of granular zero-valent iron. In G.B. Wickramanayake, and R.E. Hinchee, Eds. Designing and Applying Treatment Technologies: Remediation of Chlorinated and Recalcitrant Compounds: The First International Conference on Remediation of Chlorinated and Recalcitrant Compounds. Columbus, OH: Battelle Press, p. 145.

WARNER, S.D., LONGINO, B.L., ZHANG, M., BENNETT, P., SZERDY, F.S., and HAMILTON, L.A. (2005). The first commercial permeable reactive barrier composed of granu- lar iron: Hydraulic and chemical performance at 10 years of operation. In G. Boshoff, and B.D. Bone, Eds., First International Symposium on Permeable Reactive Barriers; IAHS Publication 298. Oxfordshire, UK: IAHS Press, p. 32.

WEBER, E.J. (1996). Iron-mediated reductive transformations: Investigations of reaction mechanism. Environ. Sci. Technol. 30, 716 .

WIECKOWSKI, A., GHALI, E., SZKLARCZYK, M., and SOBKOWSKI, J. (1983). Behaviour of iron electrode in $\mathrm{CO}_{2}$-saturated neutral electrolyte-II. Radiotracer study and corrosion considerations. Electrochim. Acta 28, 1627.

WILKIN, R.T. and PULS, R.W. (2003). Capstone Report on the Application, Monitoring, and Performance of Permeable Reactive Barriers from Ground-Water Remediation; Volume 1, Performance Evaluations at Two Sites. Report \#EPA/ 600/R-03/045A. Washington, DC: United States Environmental Protection Agency.

WILKIN, R.T., PULS, R.W., and SEWELL, G.W. (2003). Long-term performance of permeable reactive barriers using zero-valent iron: Geochemical and microbiological effects. Groundwater 41, 493.

WILKIN, R.T., SU, C., FORD, R.G., and PAUL, C.J. (2005). Chromium-removal processes during groundwater remediation by a zerovalent iron permeable reactive barrier. Environ. Sci. Technol. 39, 4599.

YABUSAKI, S., CANTRELL, K.J., SASS, B.M., and STEEFEL, C. (2001). Multicomponent reactive transport in an in situ zero-valent iron cell. Environ. Sci. Technol. 35, 1493.

YOON, S.W., GAVASKAR, A.R., SASS, B.M., GUPTA, N., JANOSY, R., DRESCHER, E., CUMMING, L., HICKS, J.E., and LIGHTNER, A. (2000). Innovative construction and performance monitoring of a permeable reactive barrier at Dover Air Force Base. In G.B. Wickramanayake, and A.R. Gavaskar, and A.S.C. Chen, Eds. Chemical Oxidation and Reactive Barriers: Remediation of Chlorinated and Recalcitrant Compounds. Columbus, OH: Battelle Press, p. 409. 
This article has been cited by:

1. Erping Bi, J. F. Devlin, Bei Huang. 2009. Effects of Mixing Granular Iron with Sand on the Kinetics of Trichloroethylene Reduction. Ground Water Monitoring \& Remediation 29:2, 56-62. [CrossRef]

2. D. Bolster, M. Barahona, M. Dentz, D. Fernandez-Garcia, X. Sanchez-Vila, P. Trinchero, C. Valhondo, D. M. Tartakovsky. 2009. Probabilistic risk analysis of groundwater remediation strategies. Water Resources Research 45:6. . [CrossRef]

3. Alok Sinha , Purnendu Bose . 2009. Interaction of Chloroethanes and Chloroethenes with Unrusted and Rusted High Carbon Iron FilingsInteraction of Chloroethanes and Chloroethenes with Unrusted and Rusted High Carbon Iron Filings. Environmental Engineering Science 26:1, 61-70. [Abstract] [PDF] [PDF Plus] 